\title{
Jewish Magic in the Syncretic Renaissance: Baking a Pizza for the Bogeyman
}

\author{
Alessia Bellusci, Villa I Tatti: The Harvard University Center \\ for Italian Renaissance Studies, USA
}

IN LATE MEDIEVAL and early modern Italy, Jews interacted with Christians on many levels, despite the restrictions imposed on them by Christian religious and secular authorities. ${ }^{1}$ They actively partook in Italian Renaissance society and culture, facilitating with their capital economic endeavors, ${ }^{2}$ procuring rare and exotic goods for their Christian neighbors and rulers, ${ }^{3}$ acting as cultural intermediaries of scientific and occult knowledge, ${ }^{4}$ and enriching the intellectual discourse of the

Contact Alessia Bellusci at via Vincigliata, 26, Fiesole, FI 50014, Italy (albellusci@gmail.com).

I am grateful to Gideon Bohak, Claire Fanger, Gad Freudenthal, Steven Harvey, Christine Hayes, Ivan Marcus, Gal Sofer, Jane Tylus, and Michael Zellmann-Rohrer for their valuable comments on earlier drafts, and to the anonymous reviewers of the journal for their detailed and insightful remarks; all remaining errors are my own. I would like to dedicate the present study to my daughter Amy, a sweet, strong, invisible presence inside me at the time I began writing the article, and to my father Martino, who traveled with Amy and me to Jerusalem, enabling me to make consistent progress with my research: they are both visible lights in my life.

1. There are many studies devoted to Italian Jewry in the Renaissance and to Jewish-Christian relations in this period. As it is not possible to mention all in a single note, I refer to Robert Bonfil, Jewish Life in Renaissance Italy, trans. Anthony Oldcorn (Berkeley, 1994), where the author inaugurates a new historiographical approach that deconstructs the idealized and apologetic interpretation of a passive Jewish assimilation into Italian Renaissance culture and peaceful cohabitation with the local population in Italy before the establishment of the ghetto, previously advanced by Attilio Milano, Cecil Roth, and Moses Avigdor Shulvass; David B. Ruderman, ed., Essential Papers on Jewish Culture in Renaissance and Baroque Italy (New York, 1992), and David B. Ruderman, Early Modern Jewry: A New Cultural History (Princeton, NJ, 2010). I refer to further specific studies on the Jews in Renaissance Italy in the following notes.

2. Maristella Botticini, "A Tale of 'Benevolent' Governments: Private Credit Markets, Public Finance, and the Role of Jewish Lenders in Medieval and Renaissance Italy," Journal of Economic History 60, no. 1 (2000): 164-89; Giacomo Todeschini, Gli ebrei nell'Italia medievale (Rome, 2018).

3. David B. Ruderman, Kabbalah, Magic and Science: The Cultural Universe of a Sixteenth-Century Jewish Physician (Cambridge, MA, 1988), 59-73; Daniel Jütte, The Age of Secrecy: Jews, Christians, and the Economy of Secrets, 1400-1800, trans. Jeremiah Riemer (New Haven, CT, 2015), esp. 37-93.

4. David B. Ruderman and Giuseppe Veltri, eds., Cultural Intermediaries: Jewish Intellectuals in Early Modern Italy (Philadelphia, 2004); Andrew D. Berns, The Bible and Natural Philosophy in Renaissance Italy: Jewish and Christian Physicians in Search of Truth (New York, 2015).

I Tatti Studies in the Italian Renaissance, volume 24, number 1. ( 2021 by Villa I Tatti: The Harvard University Center for Italian Renaissance Studies. All rights reserved. 0393-5949/2021/2401-0005\$10.00 
time with new Jewish literary and artistic creations inspired by Renaissance themes. ${ }^{5}$ While preserving their specific identity, Italian Jews incorporated within their own tradition social behaviors, forms of knowledge, and beliefs of the surrounding majority culture, often reworking and adapting them to their Jewish sensibility. Concurrently, their ancestral lore became a source of inspiration for a few influential Christian thinkers of the time: the rise of Christian kabbalah in fifteenth-century Florence as Giovanni Pico della Mirandola's synthesis of Hermetism and Jewish kabbalistic truths is a tribute to this Christian elitist fascination with Jewish culture, but also testament to a sophisticated Jewish-Christian intellectual partnership. ${ }^{6}$

Especially in recent years, scholars have investigated the extensive cultural exchange between Jewish and Italian Renaissance culture through the lens of magic. ${ }^{7}$ Edward Goldberg's and Daniel Jütte's excellent studies on, respectively, Benedetto Blanis (ca. 1580-1647) and Abramo Colorni (ca. 1544-99) have shown that Italian learned and polyhedric Jews-though not necessarily luminaries, as in the case of the quite ordinary Blanis-exploited their alleged reputation of masters of the occult to strengthen their social and economic positions and their ties with the ruling authorities. ${ }^{8}$ They traded in "curious' and 'forbidden' writings, particularly arcana on the Inquisition's Index of Prohibited Authors and Books." 9 The Jews unveiled scientific, mystical, occult, and magical traditions-at the time interrelated and

5. Ruderman, Essential Papers, esp. 45-104; 170-279; Gal Sofer, "Lover, Son and Prophet: Magic and Kabbalah in the Autobiography of Yohanan Alemanno" [in Hebrew], Tarbiz 86, no. 4 (2019): 66394; Mauro Perani, “The Illuminated Hebrew Manuscript in Renaissance Italy," and Andreina Contessa, "Art and Jewish Patronage in Renaissance Italy," in The Renaissance Speaks Hebrew, ed. Giulio Busi and Silvana Greco (Milan, 2019), 78-95 and 158-67, respectively.

6. The bibliography on the subject is extensive. See Francis A. Yates, Giordano Bruno and the Hermetic Tradition (London, 1964); Chaim Wirszubski, Pico della Mirandola's Encounter with Jewish Mysticism (Cambridge, MA, 1998); Moshe Idel, Kabbalah in Italy 1280-1510: A Survey (New Haven, CT, 2011); Flavia Buzzetta, Magia naturalis e scientia cabalae in Giovanni Pico della Mirandola (Florence, 2019).

7. Although the term "magic" is often considered inadequate in scholarship because of its problematic and prejudicial history-see David Frankfurter, ed., Guide to the Study of Ancient Magic (Leiden, 2019), 29-35-I employ it to refer to ritual behaviors and techniques based on either the manipulation of elements, the power of speech (i.e., linguistic magic), or both, and aimed at producing a specific result in a contingent situation-all phenomena that I inevitably study from an etic standpoint; see Alessia Bellusci, "Introduction," Dream Requests in the Middle East: The History of the "She 'elat Halom" from the Medieval Era back to Late Antiquity (Leiden, forthcoming). Throughout the article, I adopt the term "user/s" to refer to individuals who practiced magic, both professional experts and laymen-the latter either paid for or benefited from the service of a magician, or dabbled in magic themselves; for an analogous use, see Gideon Bohak, Ancient Jewish Magic (Cambridge, 2008).

8. Edward Goldberg, Jews and Magic in Medici Florence: The Secret World of Benedetto Blanis (Toronto, 2011); Jütte, Age of Secrecy.

9. Goldberg, Jews and Magic, 119; see also Federico Barbierato, Nella stanza dei circoli: Clavicula Salomonis e libri di magia a Venezia nei secoli XVII e XVIII (Milan, 2002); Marina Caffiero, Legami pericolosi: Ebrei e cristiani tra eresia, libri proibiti e stregoneria (Turin, 2012), 5-117. 
almost indistinct spheres of knowledge-making them accessible to their eager patrons. ${ }^{10}$ When unable to decipher themselves the secrets of Jewish occult lore, they could count on the right connections within their Jewish network and consult with more experienced Jewish professionals. ${ }^{11}$

But the Jewish-Christian encounter in the realm of magic and the occult went beyond the cultural mediation enabled by the Jewish side for economic and social gain. It was often the expression of a genuine Jewish appreciation of the culture of the surrounding majority and of the many achievements of the intellectual renewal of the period. In his masterful study, David B. Ruderman demonstrates how the Jewish physician-previously failed banker-Abraham Yagel (1553-1623?) was a true Renaissance man in that he attempted to explain the world and the wonders of God's creation by scrutinizing different non-Jewish intellectual traditions along with his Jewish rabbinic and kabalistic learning. He voraciously read classical and Neoplatonic writings vis-à-vis Jewish sources-often showing how the latter prefigured or improved the former-in a consistent attempt to harmonize them into an all-embracing scientific theory where medical knowledge was deeply interconnected with religion, astrology, demonology, and magic. Regardless as to whether Yagel's inclusion of non-Jewish texts within his Jewish library and system of knowledge was an effort to dignify Judaism within late Renaissance culture in a period of marked Jewish social and economic struggles-as sustained by Ruderman ${ }^{12}$ - it certainly demonstrates a remarkable Jewish openness to external traditions, especially when pertaining to magic, and a striking ability to integrate them within mainstream Jewish intellectual categories. ${ }^{13}$

This fervent interest in magic and the occult shared by Jewish and Christian intellectuals and the resulting mutual resonance of the respective traditions had parallels on a more popular level. ${ }^{14}$ Inquisitorial files point to an intense exchange of magical traditions-both on a theoretical and practical level-between Jews and

10. The marked interconnectedness of these fields and subfields of knowledge is evident in the material gathered and discussed in Ruderman, Kabbalah.

11. Goldberg, Jews and Magic, 120-21.

12. Ruderman, Kabbalah, 6.

13. For other Italian Jews who-like Yagel-integrated traits of the local culture within their intellectual vision, see Alessia Bellusci, "There Once Was a Frog: A Seventeenth-Century Dried Frog in Ms. ROS 77," Magic, Ritual, and Witchcraft 15, no. 3 (2020): 336-60.

14. By mentioning Jewish and Christian intellectuals and laymen interested in magic separately, I do not mean to suggest that they necessarily-or always-embraced different magical traditions. In fact, the dichotomy between "magic" and "elite" discourse emerges only in sources produced by individuals or groups who opposed magic and, allegedly, did not engage in it; these sources are not representative of actual practice. For a similar approach, see Ra'anan Boustan and Joseph E. Sanzo, "Christian Magicians, Jewish Magical Idioms, and the Shared Magical Culture of Late Antiquity," Harvard Theological Review 110, no. 2 (2017): 217-40, 220 n. 8; Caffiero, Legami pericolosi, 129. 
Christians and, to a certain extent, to a fusion of magical practices, especially in the case of the "superstizioni semplici" (simple superstitions) - that is, apotropaic amulets, charms, and forms of prayer finalized at the achievement of mundane goals, as opposed to learned magic. ${ }^{15}$ Christian clients-both laymen and ecclesiasticspurchased amulets and services in the domain of magic from Jewish experts. ${ }^{16}$ Conversely, Christian magical practices were integrated into Jewish culture, as in the case of using representations of the Virgin for facilitating childbirth. ${ }^{17}$

This important chapter of Jewish and Renaissance history has been established chiefly through the use of either Italian archival sources (ecclesiastical and government deliberations, judicial and inquisitorial files, police records, legal contracts, letters) or the autobiographical and literary production of individual Jews. The first describe the cultural attitudes of the predominant Christian culture, on the ways Jews broadcasted themselves to their Christian patrons and on the extent to which they chose to share their ancestral lore. The latter reflects the mental world of individual Jews mainly belonging to an upper class of rabbis, physicians, kabbalists, and bibliophiles. This double evidence stemming from, respectively, a Christian and Jewish context—which itself has been seldom addressed in scholarship—has not been explored yet vis-à-vis another outstanding textual corpus: the many manuscripts of Jewish magic extensively copied in medieval and early modern Italy.

This unfortunate lacuna in both the fields of Jewish and Italian studies mostly reflects a broader scholarly prejudice against Jewish magic, which is still often perceived as a phenomenon external to Jewish culture. Despite recent studies that show the existence of a long and specific Jewish magical tradition, the majority of the sources-and especially those from medieval and modern Italy, among which there are many Hebrew or Judeo-Italian (i.e., Italian in Hebrew characters) codices-are still unpublished and often even uncataloged. ${ }^{18}$ The potential intake of these enchanting and yet neglected codices is crucial for our understanding of the circulation and refashioning of Jewish magic and its relationship with Christian occult traditions-both learned and popular - as well as for the history of Jewish-Christian cultural encounters in everyday life. A thorough investigation of Italian manuscripts

15. Caffiero, Legami pericolosi, 123.

16. Caffiero, Legami pericolosi, 122.

17. Caffiero, Legami pericolosi, 137.

18. For a thorough overview of the field of Jewish magic, see Gideon Bohak, "Prolegomena to the Study of the Jewish Magical Tradition," Currents in Biblical Research 8 (2009): 107-50. For medieval codices of Jewish magic, see Gideon Bohak, A Fifteenth-Century Manuscript of Jewish Magic: MS New York Public Library, Heb. 190 (Formerly Sassoon 56); Introduction, Annotated Edition and Facsimile [in Hebrew], 2 vols. (Los Angeles, 2014), 1:9-10. On Judeo-Italian, see Aaron D. Rubin, "Judeo-Italian," in Handbook of Jewish Languages: Revised and Updated Edition, ed. Lily Kahn and Aaron D. Rubin (Leiden, 2017), 298-365. 
of Jewish magic would enable us to better understand, for instance, the confession given by the Jew Simone Narni to the Sant'Uffizio, according to which he used to whisper in the ear of Jewish women in labor Exodus 11:8, first in Hebrew and then in Italian. ${ }^{19}$ Late medieval and early modern Hebrew magical codices of Italian origin - some of which are discussed in this article-demonstrate that this apotropaic practice was widespread within the Jewish world: the verse from Exodus was either recited at the presence of the parturient—as Simone used to do-or inscribed on an amulet tied to the woman's navel. ${ }^{20}$ Similarly, a detailed analysis of Italian Jewish magical sources would provide further insight on popular practices such as the "operazione della caraffa" (operation of the saucer) or inghistara-that is, a form of divination by gazing at the water spilled into a vase-performed by Jews and Christian alike for finding lost properties and hidden treasures, one of the most common magical techniques according to inquisitorial files. ${ }^{21}$ Recipes for the same purpose are found in Italian manuscripts of Jewish magic, some of which are studied in this article. ${ }^{22}$ Remarkably, both Christian and Jewish sources mention the angel Mariel Sar ha-Ṣluhit (Mariel the "prince of the saucer"), spelled "Sciar Azalochit" in inquisitorial files, ${ }^{23}$ and refer to the specific prayer known as the "white angel spell." ${ }^{24}$ These are but a few examples suggesting how the corpus of manuscripts of Jewish magic can complement the sources more commonly used in scholarship for reconstructing Jewish-Christian interactions in magical practice. By adding this fascinating material to the historical equation, we would gain a more extensive and nuanced portrait of Jewish magic in Italy and its many implications for both Jewish and Italian intellectual history and material culture.

19. Caffiero, Legami pericolosi, 136.

20. Alessia Bellusci, "Jewish Magia in Renaissance and Baroque Italy: Preliminary Notes on Ms. GFC 325," in Cabbala, ed. Flavia Buzzetta, Cahier Accademia 11 (2018): 23-42, 35-36, and "Un manuale moderno di magia in ebraico ed italiano dalla Collezione di Lisa e William Gross," in L'eredità di Salomone: La magia ebraica in Italia e nel Mediterraneo, ed. Emma Abate and Saverio Campanini (Florence, 2019), 279-313, 304-5. The practice of reciting a psalm (Pss. 19 and 24) to assist a woman in labor is also documented in the writings of Flavius Mithridates, who was active in the circle of Pico della Mirandola, and in manuscripts of Christian magic; see Gal Sofer, "The Magical Cosmos of Yohanan Alemanno: Christian and Jewish Magic in the Service of a Kabbalist," Jewish Thought 2 (2020): 65-92, 68-71.

21. Ruth Martin, Witchcraft and the Inquisition in Venice, 1550-1650 (Oxford, 1989), 113-21 and 167-68; Oscar Di Simplicio, Autunno della stregoneria: Maleficio e magia nell'Italia moderna (Bologna, 2005), 74-76.

22. New York, Jewish Theological Seminary Library, Elkan Nathan Nathan Adler Collection, 2948.10 (hereafter JTSL ENA 2948.10), r, 10-17; Tel Aviv, Gross Family Collection Trust, It. 011 016, 325 (hereafter GFC 325), 38r-39v; and New York, Jewish Theological Seminary Library, 1729, Elkan Nathan Adler Collection, 3832 (hereafter JTSL 1729), 46-48.

23. Caffiero, Legami pericolosi, 158.

24. JTSL ENA 2948.10r, 14-15. For the prayer in inquisitorial records, see Martin, Witchcraft, 117. 
The following remarks will focus on the textual history of a specific magical technique for becoming invisible found in Italian manuscripts of Jewish magic. As painfully enigmatic and fragmentary the insight emerging from such a study may be, they will allow us to glimpse the lived religion of premodern Italian Jews and the vibrant encounter between Judaism and Italian Renaissance culture in the overlapping sphere of magic.

Disappearing by magical means has prompted fascination since antiquity, as demonstrated by the considerable number of recipes for invisibility found in magical compendia throughout the world. ${ }^{25}$ The Jewish magical tradition includes various techniques for becoming invisible, which range from simply repeating biblical verses to complex procedures that involve the use of magical beans and rings. ${ }^{26}$ The technique for invisibility examined in this article-documented at least since the fourteenth century-stands out for its (apparently) syncretic nature: it consists in preparing a "pizza" and offering it to a demonic figure-referred to as "the black man"-while standing at a crucifixion site and reciting a magical formula, which is now unintelligible to us but which may have originally alluded to the Greek myth of Perseus and the Gorgon. Certain traits of this magical behavior can be traced back to late antique Greco-Egyptian magic, while the textual transmission associated with it reflects a complex history of cross-cultural borrowings, appropriation, and translation.

I was able to identify five Hebrew codices dated between the fourteenth and the seventeenth centuries that preserve recipes in Hebrew that attest to this specific behavior, thus indicating that, at least since the Middle Ages, the technique was transmitted and used by Jews. ${ }^{27}$ Significantly, all the Hebrew sources are directly linked with Italy, as they are either part of codices of Italian provenance or are written in a Hebrew deeply influenced by the Italian language. Furthermore, two of them

25. Richard L. Phillips, In Pursuit of Invisibility: Ritual Texts from Late Roman Egypt (Durham, NC, 2009), "Blinding as a Means of Becoming Invisible: Reflections on the Context of P.Oxy. LVIII.3931," Illinois Classical Studies 35/36 (2010-11): 111-20, and "On the Outside Looking In: Pliny's Natural History and the Portrayal of Invisibility Rituals in the Latin West," Memoirs of the American Academy in Rome 56/57 (2011-12): 37-62; Richard Kieckhefer, Magic in the Middle Ages (Cambridge, 1990), 7 8, and Forbidden Rites: A Necromancer's Manual of the Fifteenth Century (University Park, PA, 1998), 59-61, 224-26, 240, and 345; Jean-Patrice Boudet, Entre science et nigromance: Astrologie, divination et magie dans l'Occident médiéval (xiie-xve siècle) (Paris, 2006), 563-68; Florence Gal, Jean-Patrice Boudet, and Laurence Moulinier-Brogi, Vedrai mirabilia: Un libro di magia del Quattrocento (Rome, 2017), 115, 337, and 339-40; Frank Klaassen and Katrina Bens, "Achieving Invisibility and Having Sex with Spirits: Six Operations from an English Magic Collection ca. 1600,” Opuscula 3 (2013): 1-14.

26. Alessia Bellusci, "Going Unseen in the Jewish Magical Tradition," Numen (forthcoming).

27. GFC 325; JTSL 1729; New York, Jewish Theological Seminary Library, 8114 (hereafter JTSL 8114); JTSL ENA 2948.10; Vatican City, Biblioteca Apostolica Vaticana, Vat. Ebr. 243 (hereafter Vat. Ebr. 243, or Vatican manuscript). 
contain an Italian version of the same recipe for invisibility, thus strengthening the relationship between this specific magical practice and an Italian-Jewish local context. ${ }^{28}$ With minor variants, the same magical recipe resurfaces in two non-Jewish sources that are also linked to Italy: a Byzantine Greek codex dated to the fifteenth century that was eventually brought to Italy and a seventeenth-century magical fragment in Italian that transmits earlier traditions. ${ }^{29}$ These Jewish and non-Jewish magical sources reveal the rationale behind this particular magical behavior that was transmitted across linguistic and cultural boundaries. More importantly, they present us with an intriguing history of cultural assimilation, adaptation, and differentiation. In following the late medieval and early modern manuscripts preserving the recipe for invisibility and unfolding the apparent incongruities of the text, I show how a magical belief imbued with late antique Greco-Egyptian magical lore circulated within different religious and cultural contexts in the Mediterranean during the Middle Ages through the mediation of a Hebrew translation or readaptation. Ultimately, it was refashioned within the specific cultural and linguistic milieu of the Jews of Renaissance Italy under the influence of their everyday encounter with local traditions.

\section{THE SOURCES}

In this section, I present five relevant Hebrew texts together with their Italian and Byzantine Greek parallels. Taking into account the analogies and dissimilarities between these texts, we can identify (1) a short version of the recipe for invisibility that is documented only in Hebrew codices (two of them also transmit an Italian translation of the Hebrew text); (2) a long version that expands on certain magical procedures-including specific formulae possibly derived from Greek and Italiandocumented in manuscript sources in Hebrew, Italian and Byzantine Greek; and (3) a cognate specimen in Hebrew, which attests to a broader use of some of the magical motifs and ritual dynamics featured in the short and long versions. These texts are being published here for the first time, with the exception of the Byzantine manuscript. $^{30}$

28. GFC 325 and JTSL 1729.

29. Paris, Bibliothèque nationale de France, grec. 2419 (hereafter BnF 2419, or Ridolfi manuscript), partially published in Armand Delatte, Anecdota Atheniensia, 2 vols. (Liège, 1927-39), 1:446-524; Leipzig, Leipzig University Library, Special Collections, Cod. Mag. 46 (hereafter Cod. Mag. 46, or Leipzig fragment).

30. Throughout the article, all English translations are mine, unless otherwise specified. The following are the signs I use in transcriptions and translations from primary sources: [text] —addition/explanation needed for the translation; text-material deleted by the copyist in the manuscript; ?-uncertain whether the preceding text or translation is correct; \or / - end of the line; $\$ or $/ /$ - end of the page. 
Each text is first contextualized within the larger manuscript compilation of which it is a part. The codices in Italian and Byzantine Greek that transmit the long version were almost certainly penned by Christians and were meant for a Christian audience, while all five Hebrew manuscripts I was able to identify were probably copied and used by Jews. Yet, as we shall see, we cannot exclude the possibility that these sources traversed religious and cultural borders. Significantly, the five Hebrew manuscripts are deeply interconnected. In addition to containing the same recipe for invisibility, they transmit other magical instructions that are analogous-with only minor variants-in the different compilations. ${ }^{31}$ This indicates that the five Hebrew manuscripts gathered and reworked textual material stemming from a shared tradition. These sources also exhibit analogous linguistic features, as they are written in an often ungrammatical Hebrew influenced by Italian, characterized by an incorrect use of prepositions, enclitic personal pronouns, and gender correspondence between nouns and adjectives, as well as by confusion between letters that are phonetically similar. ${ }^{32}$ These specific linguistic features point to a cultural milieu in which the Jews were exposed to Italian dialects to a great degree and in which they felt the need to express or clarify the text they were composing (or copying) in the idiom of the local population rather than in their religious and identity language. This interesting linguistic phenomenon is characteristic of literary production more broadly of late medieval Italian Jews, who not only mastered Italian-as demonstrated by their correspondence with Italian authorities, employers, and patrons-but also used Italian terminology in their personal writings in Hebrew (i.e., words from Italian vernaculars in Hebrew letters). Judeo-Italian expressions were employed by Jews of different social and cultural classes for rendering terms that were not part of the Hebrew vocabulary, as well as for common words. ${ }^{33}$ As of the late sixteenth century, several Jews-among whom rabbis and intellectuals who were certainly well acquainted with Hebrew-began using Italian (not only isolated words in Italian) for their private writings and, eventually, Italian Jews started composing their community protocols (pinqasim) in Italian. ${ }^{34}$ The linguistic fluidity of Italian Jews also emerges in inquisitorial records. We have already noted that the

31. Bellusci, "Jewish Magia," 23-42, and "Un manuale moderno," 279-313.

32. For space concerns, I cannot comment upon the specific spelling, grammatical, and syntactic mistakes in the texts edited below; however, note especially the indiscriminate use of the prepositions of place le- (to, idea of movement to a place) and be- (in/at, idea of state in a place), which can be explained by the fact that in Italian they might be translated by the same prepositions in or $a$, despite their different grammatical function.

33. Alessandra Veronese, "Espressioni del volgare italiano scritte in ebraico nei diari di viaggio di Mešullam da Volterra e Mošeh Basola (secoli XV-XVI)," Materia Giudaica 22 (2017): 259-66.

34. Robert Bonfil, "Changing Mentalities of Italian Jews between the Periods of the Renaissance and the Baroque," Italia 11 (1994): 61-79, esp. 64-66. 
seventeenth-century Jew from Rome Simone Narni used to translate spells and magical prayers into Italian to make them intelligible to his clients. ${ }^{35}$ In many cases, the different types of Jewish camí confiscated by the Sant'Uffizio (camí is clearly the Italianized form of the Hebrew qame' $a$, or amulet) were inscribed in Hebrew but included passages in Latin and Italian. ${ }^{36}$ If this linguistic pastiche was functional to the logic of magic-in different historical contexts, the language of magic is intentionally constructed as foreign, exotic, and hybrid ${ }^{37}$-it is also symptomatic of a precise cultural choice by Jews who lived in close contact with their Italian Christian neighbors, expressed themselves in the local idiom, and very likely consulted technical magical literature in Italian.

\section{New York, Jewish Theological Seminary Library, Elkan Nathan Adler Collection, 2948.10}

The fragment JTSL ENA 2948.10 is a single paper leaf written on both sides that can be paleographically dated to the fourteenth or fifteenth century and that was uncovered in the Cairo Genizah, that is, the storeroom of the Ben Ezra Synagogue in Cairo discovered at the end of the nineteenth century. ${ }^{38}$ It originally belonged to a longer medico-magical compendium, of which more than a dozen additional leaves can be identified in the Cairo Genizah. ${ }^{39}$ For the most part, the compendium was apparently made up of segullot (pl. of segullah, that is, magical property or remedy) in Ladino (Judeo-Spanish, namely, Spanish in Hebrew characters). Like the rest of the compendium, the verso of the fragment preserves five segullot in Ladino, while the recto features two magical recipes in a not very proficient Hebrew. The first-edited and translated below-is aimed at attaining invisibility and is representative of the textual magical tradition studied in this article (1-9). The second gives instructions for retrieving a treasure through the "operation of the saucer" (10-17) and includes a Judeo-Italian version of the above mentioned "white angel spell" which often resurfaces in inquisitorial files. Within the medico-magical compendium, the two recipes represent an anomaly both from a content and linguistic perspective and might have been copied from a different source. Furthermore, both

35. Caffiero, Legami pericolosi, 136.

36. Caffiero, Legami pericolosi, 65-66, 169.

37. See Boustan and Sanzo, "Christian Magicians," and the bibliography discussed there.

38. On magical fragments uncovered in the Cairo Genizah, see Gideon Bohak, "Towards a Catalogue of the Magical, Astrological, Divinatory and Alchemical Fragments from the Cambridge Genizah Collections," in "From a Sacred Source": Genizah Studies in Honour of Professor Stefan C. Reif, ed. Ben Outhwaite and Siam Bhayro (Leiden, 2010), 53-79.

39. New York, Jewish Theological Seminary Library, Elkan Nathan Adler Collection, 2712.49; 2713.17; 2799.1-9; 2815.8; 3338.3-4; 3672.1 (unpublished). 
magical texts are documented — albeit with differences — in at least three other Hebrew magical codices of clear Italian provenance that I discuss below (JTSL 8114, GFC 325, and JTSL 1729). Therefore, even though the Genizah medico-magical compendium overall points to a Jewish-Spanish milieu, the two recipes in Hebrew preserved on JTSL ENA 2948.10 recto were either copied from an Italian or JewishItalian source or reworked in an Italian context before being appropriated in the anthology:

להעלם מכל אדם קח מעץ מתלוי בו| האדם ועשה אש ממנו ואחר קח סולת| ודבש ועשה עוגה

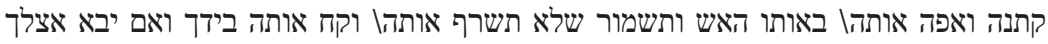

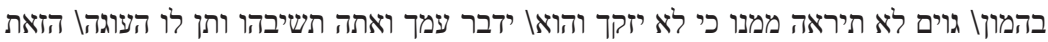

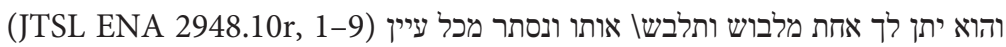
[To disappear from [the sight of] every person. / Take [wood] from a tree on which a man [lit. the man] / is hanged and make from it a fire. And afterward, take semolina / and honey and make a small round bread and bake it / on that fire, making sure not to burn it. / And take it in your hand and, if he will come to you in a great / multitude [of demons?], ${ }^{40}$ do not be scared of him, because he will not hurt you. And he / will talk to you and you shall respond to him and give him this / cake and he will give you a garment and you shall wear / it and [you will be] hidden from every eye.]

\section{Tel Aviv, Gross Family Collection Trust, 325 and Its Twin Copy New York, Jewish Theological Seminary Library, 1729}

The same version of the recipe for invisibility is transmitted in two manuscripts of Jewish magic that were probably penned in seventeenth-century Italy: GFC 325, a miscellaneous anthology of kabbalistic excerpts, Solomonic seals, and magical recipes, which today is part of the private collection of Judaica of Lisa and William Gross in Tel Aviv, ${ }^{41}$ and its lost twin JTSL 1729, which is preserved at the Jewish Theological Seminary Library in New York. ${ }^{42}$ The two codices measure approximately the same and exhibit analogous visual features and structure. ${ }^{43}$ With insignificant variants,

40. The biblical expression בהמון גוים (Gen. 17:5) literally means "with many gentiles/nations." Although recipes for invisibility were often used for practical aims within the Jewish traditions-namely, for self-defense against potential assaults-I do not think that the expression refers to a horde of gentiles.

41. Bellusci, "Jewish Magia"; Bellusci, "Un manuale moderno di magia." For the talismanic use of the seals of the Clavicula Salomonis (The key of Salomon), the most famous Renaissance grimoire, see Barbierato, Nella stanza dei circoli, 48.

42. In the Catalog of Practical Kabbalah Mss in JTS Library, prepared by Martin S. Cohen in 198283 and never published (kindly made available to me by Ivan Marcus), JTSL 1729 is dated to the eighteenth century.

43. GFC 325 measures $13.6 \mathrm{~cm} \times 9.5 \mathrm{~cm}$, while JTSL $1729,12.7 \mathrm{~cm} \times 9.4 \mathrm{~cm}$. 
they transmit the same collection of magical recipes and remedia, which are eightyone in GFC 325 and eighty-three in JTSL 1729. This is an extremely rare finding in the context of manuscripts of Jewish magic, as almost every single Hebrew magical manuscript constitutes a new textual creation and is unique in the form in which it is documented. ${ }^{44}$ Both manuscripts-which may have been written by the same hand-feature the different magical recipes first in Hebrew and then in Italian (in Latin letters).

This hybrid linguistic configuration may reflect different types of cultural encounters between Jews and Christians in early modern Italy. The twin codices may have been copied by an Italian Jew or a Christian convert for a Christian intellectual interested in learning Jewish Kabalistic and magical truths, according to the model of Jewish-Christian partnership inaugurated by Pico della Mirandola and his Jewish (or ex-Jewish) associates. This hypothesis seems particularly plausible in light of the Jewish-Christian nature of the kabalistic excerpts found in GFC $325 .{ }^{45}$ Yet the bilingualism that characterizes the two codices may also reflect the negotiated identity of Italian Jewish experts of magic and/or the diverse linguistic and cultural identities of their clients. Having the same recipe both in $\mathrm{He}-$ brew and Italian would have enabled the professional who owned the book to easily and quickly copy the requested amulet in the appropriate language for the specific client-Hebrew for Jews, Italian for Christians and those Jews who had not mastered their ancestral language. Having the Italian text in parallel with the Hebrew would have served a Christian professional interested in selling Jewish recipes to his/her Christian clients. More broadly, the bilingualism of GFC 325 and JTSL 1729 reflects the specific physiognomy of early modern Italian Jewry and a shared Jewish-Christian magical culture.

The specific terminological and grammatical features of the Hebrew and Italian sections of the twin codices may add further insight into the linguistic and cultural background of their authors and readership. The Hebrew recipes often exhibit Aramaisms and find textual parallels in earlier Hebrew magical material, thus suggesting they are copies of earlier texts. Yet they also make extensive use of Italian nomenclature for the materia magica and medica and include several grammatical mistakes that reflect the influence of Italian language and culture. It seems logical that the recipes in Italian-which in both manuscripts come always second to the Hebrew text-were translations of the Hebrew, added ad hoc by the person who copied the codex. Yet these alleged Italian translations also exhibit many archaisms that can be traced back to different medieval Italian vernaculars and would have

44. Bohak, Fifteenth-Century Manuscript, 10-11.

45. Bellusci, “Jewish Magia," 26-27; Bellusci, “Un manuale moderno,” 286-89. 
been anachronistic in a modern translation. It is possible, then, that the collection of magical recipes in Hebrew and Italian translation transmitted in GFC 325 and JTSL 1729 copied an earlier bilingual source. Some of the Hebrew recipes preserved in the anthology may have originally been composed on the basis of Italian sources (e.g., Italian herbaria, secreta, and remedia) and/or within Jewish circles in Italy. Furthermore, some of the recipes in Italian-either matched or not by their equivalent in Hebrew-may have circulated independently before being collected and copied by the author into the compendium.

Below I offer a transcription of the recipe for invisibility in Hebrew and Italian according to GFC 325 (figs. 1-2). ${ }^{46}$ I then provide an English translation of the recipe based on the Hebrew text, but with attention to the different nuances that characterize the Italian text, which exhibits several archaisms and ancient dialectal forms:

שלא יראך אדם| קח קמח סולת ודבש ולך במקום שיש| שם תלוי וקח מן העץ אשר הוא|

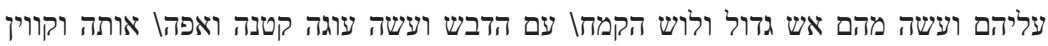

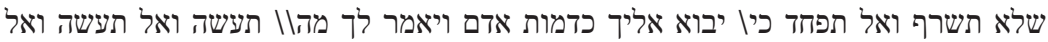

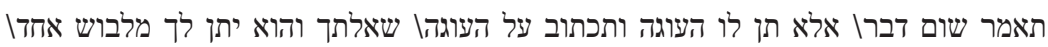

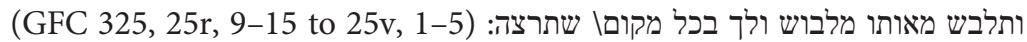

Che non ti veda nissuno / Piglia farina di fiore, e / và in loco che vi sia là / un appiccato, piglia del / legno di quell'albero che / stà detto appiccato, e fanne / un foco, impasta detta farina / e fanne una piccola pizza / e cocela, ma bada che / non si abbruggia, e non // aver paura, che ti compa-/rirà un uomo, e ti dirà cosa/ fai, e tù non fare ne dire / alcuna cosa, mà scrivi / sopra detta pizza la tua do-/manda, e dalla al detto uomo/ e ti darà un vestito, ves-/tasi di quello, e và dove/ vuoi. (GFC $325,25 \mathrm{v}, 6-15$ to $26 \mathrm{r}, 1-9$ )

[That no man shall see you. / Take fine flour and honey ${ }^{47}$ and go to a place where / someone is hanged, and take from the tree ${ }^{48}$ on which / he is hanged [lit. which he is on] and make from it a big ${ }^{49}$ fire. And knead the flour / with honey and make a little round bread [a little pizza in the Italian version] and bake / it, but pay attention that it does not burn. And do not fear, when / [an apparition] in the image of a $\operatorname{man}^{50}$ will come to you and will tell

46. The variants in JTSL $1729,24 \mathrm{v}, 5-14$ to $25 \mathrm{v}, 1-7$ are insignificant.

47. Omitted in the Italian text (preserved, though, in JTSL 1729, 25r, 9-10 and 11).

48. The Italian text expands the Hebrew מן העץ (from the wood/tree) in "del legno di quell'albero" (from the wood of that tree).

49. Omitted in the Italian text (preserved, though, in JTSL 1729, 25r, 6).

50. The Italian text does not translate the expression כדמות (in the image of), indicating that the copyist did not understand the technical expression כדמות אדם (in the image of a man), often documented in Jewish divinatory texts. 


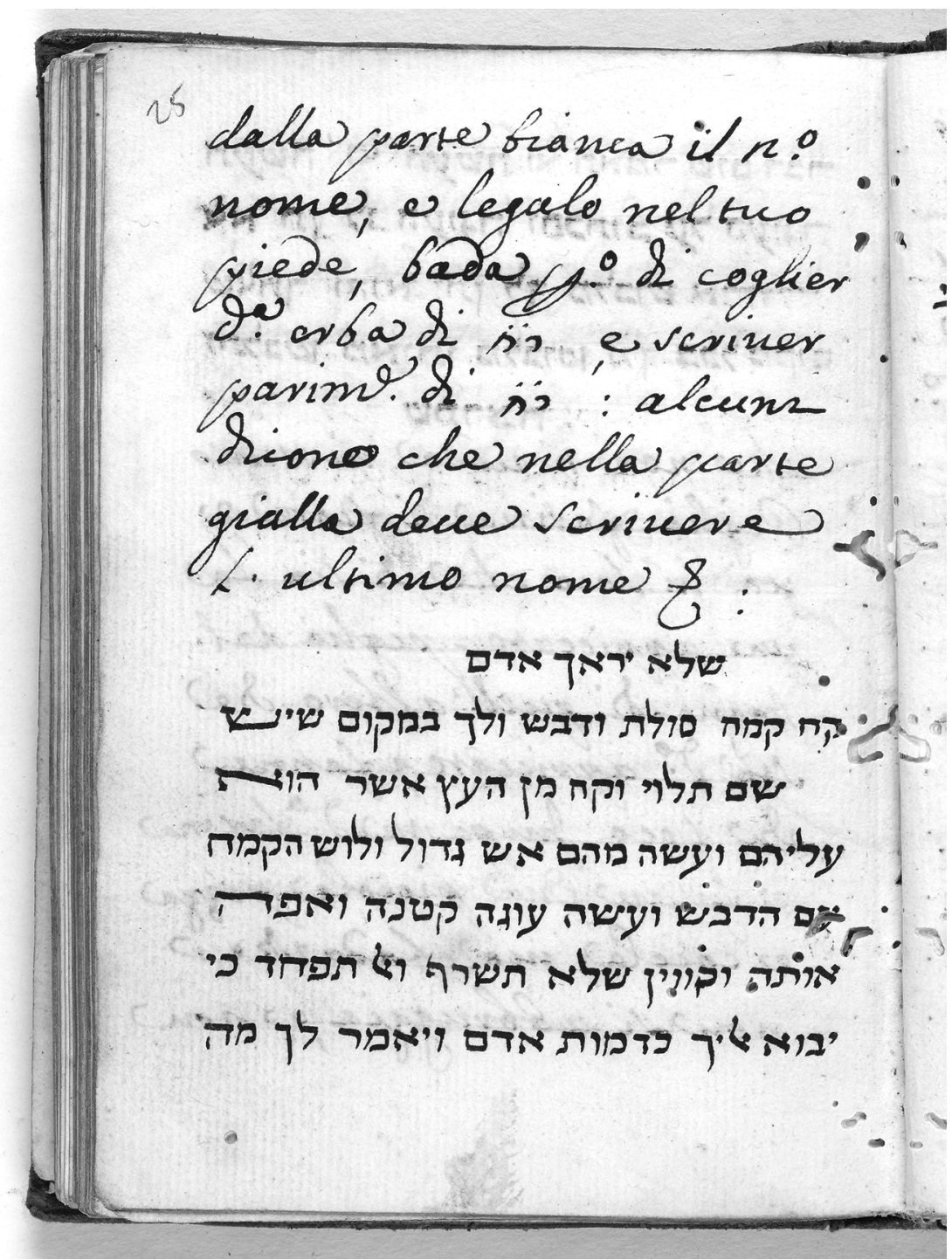

Figure 1. Recipe for invisibility in Hebrew (short version). Tel Aviv, Gross Family Collection Trust, It. 011 016, 325, 25r. Reproduced with the kind permission of the Gross Family Collection Trust. Color version available as an online enhancement.

you what // to do. And do not do and do not say anything / but give him the round bread and write on the round bread / your question. ${ }^{51}$ And he will give

51. In the Italian text, the order of the sentence is inverted (preserved, though, in JTSL 1729, 25v, $3-5$, "dalli la pizza, mà che sia scritto sopra detta pizza quello che vuoi"). 


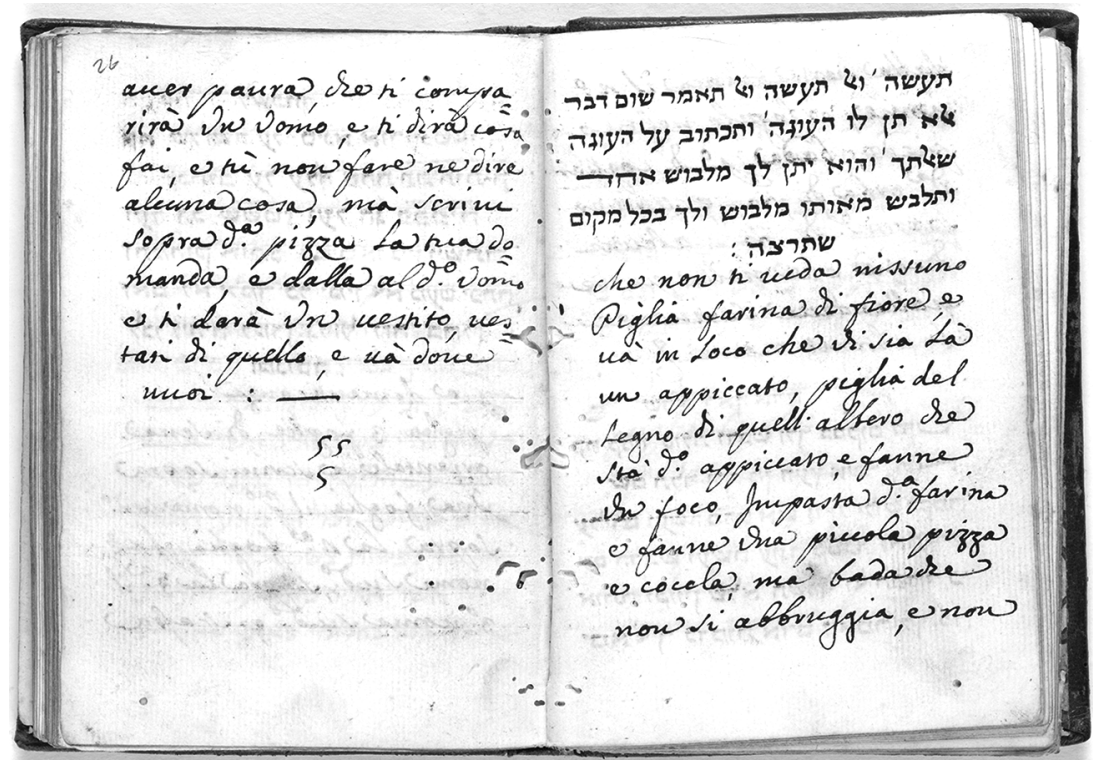

Figure 2. Recipe for invisibility in Hebrew and Italian (short version). Tel Aviv, Gross Family Collection Trust, It. 011 016, 325, 25v and 26r. Reproduced with the kind permission of the Gross Family Collection Trust. Color version available as an online enhancement.

you a garment / and you shall wear the same garment and go to every place / you wish [while being invisible].]

Vatican City, Biblioteca Apostolica Vaticana, Ebr. 243

A longer and more elaborate version of the recipe for invisibility is in Vat. Ebr. 243, a Hebrew paper codex of 64 leaves_-half of which are blank-today preserved at the Vatican Library. ${ }^{52}$ Most of the codex is written in Hebrew in a single Italian semi-cursive script that can be dated to the year 1500 and preserves a collection of almost 180 magical recipes for different purposes $(4 \mathrm{r}-21 \mathrm{v})$ and a version of the magical composition Sefer Shimmush Tehilim (The Book of the Magical Use of Psalms) $(49 \mathrm{v}-55 \mathrm{v}) .^{53}$ The manuscript also contains a prayer in Judeo-Italian written by an Ashkenazi hand, as well as several other brief magical texts in Hebrew

52. Umberto Cassuto, I manoscritti palatini ebraici della Biblioteca Apostolica Vaticana e la loro storia (Vatican City, 1935), 71; Benjamin Richler, ed., Hebrew Manuscripts in the Vatican Library: Catalogue; Compiled by the Staff of the Institute of Microfilmed Hebrew Manuscripts, Jewish National and University Library, Jerusalem (Vatican City, 2008), 180-81. The codex measures $13.1 \times 10.5 \mathrm{~cm}$.

53. Bill Rebiger, Sefer Shimmush Tehillim (Tübingen, 2010); the copy in Vat. Ebr. 243 is discussed on 65-66. 
and Latin added by different hands. ${ }^{54}$ As a few other Hebrew manuscripts in the Vatican Library, it reports titles and notes in a red-brown ink added by a certain "L. Flaminio" who was identified by Umberto Cassuto with the Sicilian humanist and orientalist Antonio Leone (Biassandro) Flaminio ( $\nmid 1513)$, professor in Rome at the end of the fifteenth century. ${ }^{55}$ If Cassuto's identification is to be trusted, the fact that the manuscript was owned by Antonio Flaminio reinforces its paleographical dating to the very beginning of the sixteenth century, suggesting that the codex did not circulate extensively_ if at all-before becoming part of the Vatican Library right after his death. ${ }^{56}$ Many of the recipes in the codex point to a nonJewish milieu, often exhibiting an imprecise use of the Hebrew language that includes many technical terms from Latin and Italian vernaculars and even formulae in Latin in Hebrew characters. Among the many examples, it is worth mentioning a recipe "for acquiring grace in front of a king or princes so that they will fulfill the user's request" based on the use of a bonnet that is referred to with the medieval dialectal Italian form fazzolo (פָּוֹ), ${ }^{57}$ or the "operation of the herb pervinca (פורוינקא)," which describes a complex magical technique of non-Jewish origin based on the conjuration of and marriage with the plant periwinkle (It. pervinca), and documented in several medieval and renaissance magical manuscripts: ${ }^{58}$

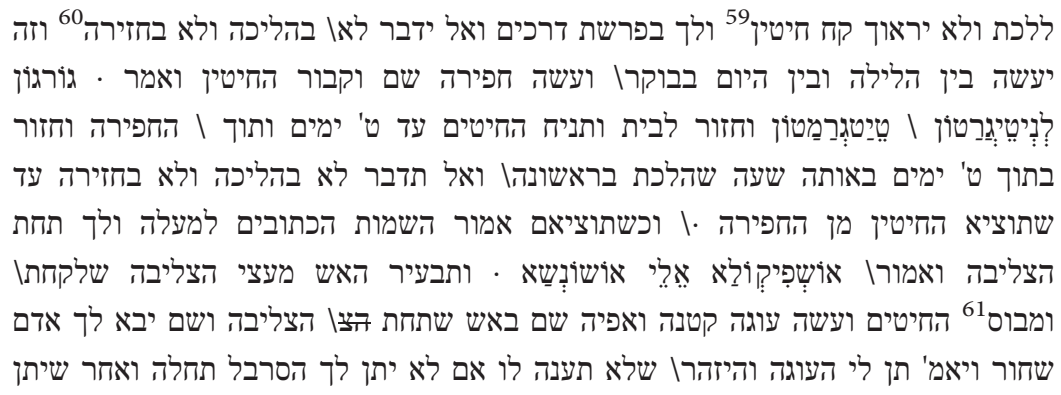

54. For a list of books and their prices preserved at the beginning of the codex, see Jean-Pierre Rothschild, "Quelques listes de livres hébreux dans des manuscrits de la Bibliothèque nationale de Paris," Revue d'histoire des textes 17 (1987): 291-346, 292 n. 7.

55. The identification with Antonio Flaminio seems more probable than the one with the more famous humanist Marcantonio Flaminio (1497/98-1550); Cassuto, I manoscritti palatini ebraici, 7174.

56. Cassuto, I manoscritti palatini ebraici, 73 and 81.

57. Vat. Ebr. 243, 6v, 1-4.

58. Vat. Ebr. 243, 7v-8v, 4; for Christian parallels, see, for instance, the fifteenth-century Italian magical codex Paris, Bibliothèque nationale de France, ital. 1524, published in Gal, Boudet, and MoulinierBrogi, Vedrai mirabilia, 261, which refers, though, to the herb valerian (valeriana).

59. Note the archaic use of the suffix -yin for the plural of rin 16r, 3, 5 and 8.

60. Note the archaic/literary form חזירה (בסרה in 16r, 4.

61. From the biblical root בוסף (later, בססירה). 
לך הסרבלו תן לו העוגה וחזור לבית מהרה ואל תביט אחריך ואל תדבר עד| שתגיע לביתך

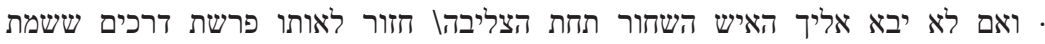

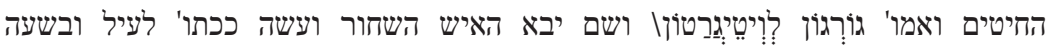
שתרצה לילך| אצוני שכול שים הסרבל עליך ולך לשלום " (Vat. Ebr. 243, 16r, 3-18)

[To go without being seen [lit. and they will not see you]. Take grains of wheat and go to a crossroad and do not speak [lit. he should not], neither / on the way there nor on the way back. And this you will do [lit. he should do] between the night and the day in the morning / and dig there a hole [lit. make there an excavation] and bury the wheat and say: GWRGWN LNYTYGRṬWN/ TYTTGRMṬWN [Gorgon Lenetegarton Teyatgrammaton?]. And go back to the house and place the wheat for nine days within / the hole [lit. excavation] and go back in 9 days at the same hour that you went the first time. / And do not speak, not on the way there and not on the way back until you take out the wheat from the digging. / And when you take them out, say the names written above. And go under a cross [lit. crucifixion] and say: / 'WSPYQWL' 'LY 'WSWPS' [ospiccola ele ossepia?]. And light a fire from the wood logs of the cross that you took / and knead the wheat and make a little round bread [lit. cake] and bake it there by the fire under / the cross. And there, a black man will come to you and say, "give me the round bread!" and be careful / not to answer him, if he does not first give you the garment. And after he gives you the garment / give him the round bread and go back to the house quickly, and do not look behind you, and do not speak until / you reach your house. And if the black man does not appear [lit. come] to you under the cross / go back to the same crossroad where you put the wheat and say GWRGWN LWYTTYGRṬWN [Gorgon Levethegarthon Teyatgrammaton?] / and there the black man will appear, and do as written above. And when you wish to leave [and not to be seen?], put on the garment and go in peace.]

\section{Leipzig, Leipzig University Library, Special Collections, Cod. Mag. 46}

A recipe for invisibility analogous to the one in the Vatican manuscript is found on a two-folia paper quire in Italian, that is, Cod. Mag. 46 (Leipzig fragment), today preserved in the collection of early modern manuscripts of magic at the Bibliotheca Albertina (Leipzig University Library) (figs. 3-4). ${ }^{62}$ Before becoming part of the Council Library of Leipzig and then of the Bibliotheca Albertina, the Leipzig 


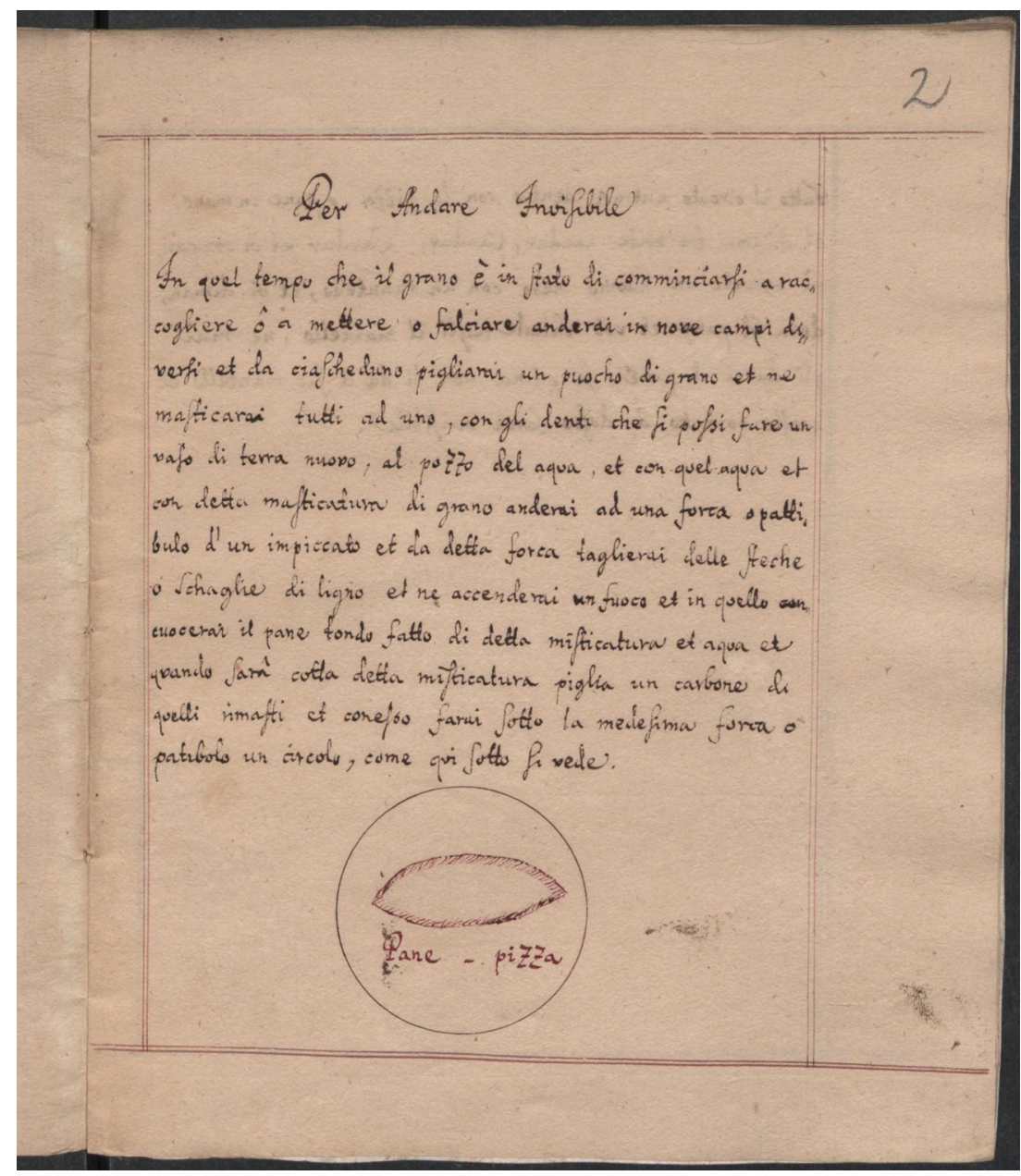

Figure 3. Recipe for invisibility in Italian (long version). Leipzig, University Library, Special Collections, Cod. Mag. 46 (on loan from the Leipzig City Library), 2r; image taken by the Leipzig University Library.

fragment belonged to the private collection of manuscripts of learned magic of Samuel Schröer, a physician active in Leipzig at the beginning of the eighteenth century. ${ }^{63}$ Schröer sold his collection in 1710 , and to advertise the sale of these rare and illicit books he printed a list of their titles, among which we find the one referring to the recipe for invisibility preserved in the Leipzig fragment. ${ }^{64}$ The year

63. Bellingradt and Otto, Magical Manuscripts in Early Modern Europe, 1-71.

64. Bellingradt and Otto, Magical Manuscripts in Early Modern Europe, 153-56. 


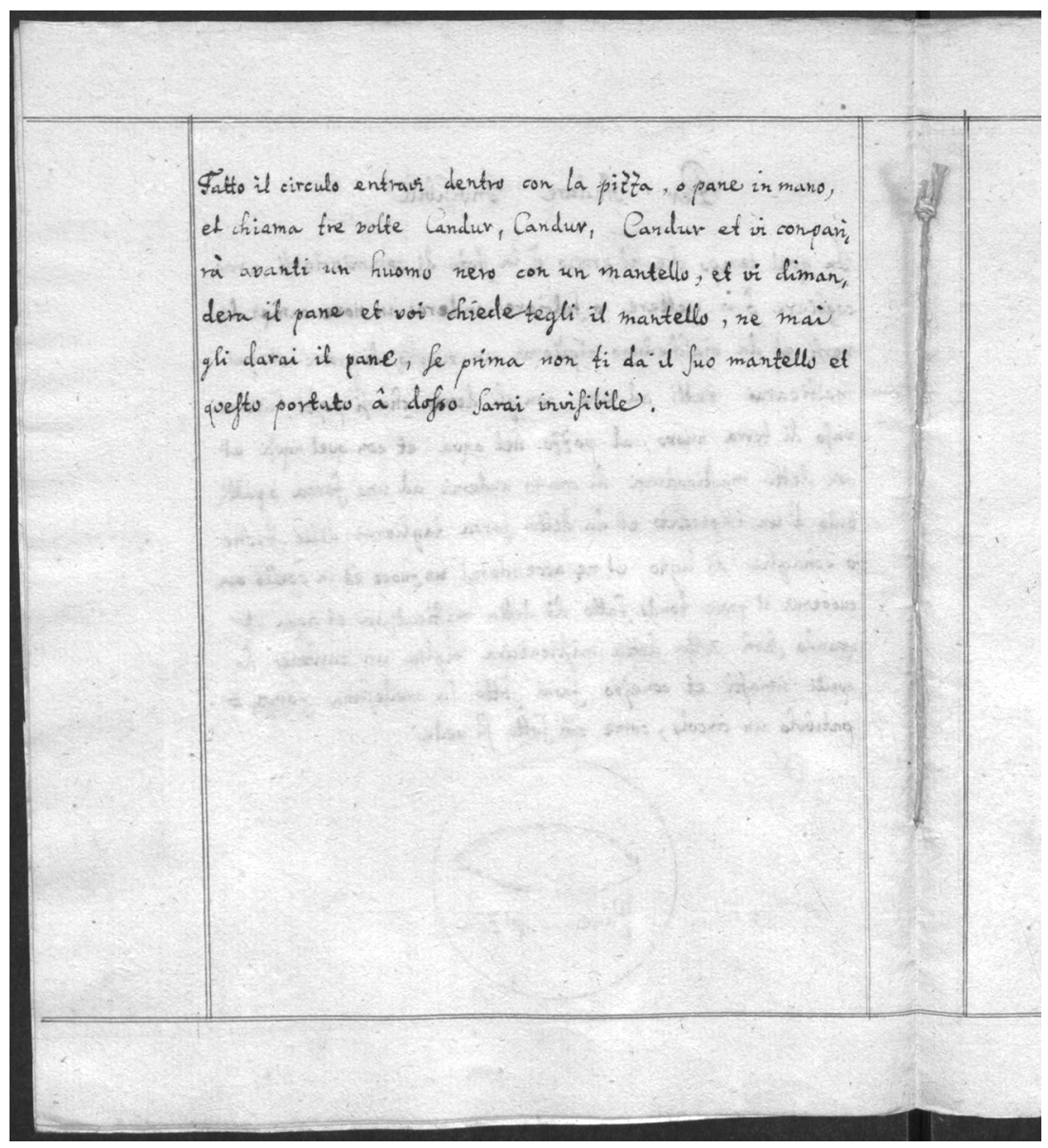

Figure 4. Recipe for invisibility in Italian (long version). Leipzig, University Library, Special Collections, Cod. Mag. 46 (on loan from the Leipzig City Library), 2v; image taken by the Leipzig University Library. Color version available as an online enhancement.

1710 is, then, the terminus ante quem for dating the manuscript. Yet, like the other manuscripts in the collection, it was copied in the seventeenth century-and possibly before-and likely transmits much earlier material. ${ }^{65}$ As in the case of the Italian recipe preserved in GFC 325 (and JTSL 1729), the many archaisms and dialecticisms detected in the Leipzig fragment may reflect a stage of Italian earlier than the period in which the codex was copied, possibly pointing to medieval or

65. Most of the manuscripts in the Leipzig collection are either copies or translations of much earlier magical texts; Bellingradt and Otto, Magical Manuscripts in Early Modern Europe, 7 and 12. 
early modern Tuscan. ${ }^{66}$ Therefore, even if it was penned in early modern Germany, the Leipzig fragment was certainly copied from an earlier Italian source:

Il velo d’invisibilta / o / Segreto Mirabile / Per andar in qualsivoglia luogo invisibile. / $123^{67}$ // Per Andare Invisibile / In quel tempo che il grano è in stato di comminciarsi a rac-/cogliere ò a mettere o falciare anderai in nove campi di-/versi et da ciascheduno pigliarai un puocho di grano et ne / masticarai tutti ad uno, con gli denti che si possi fare un / vaso di terra nuovo, al pozzo del aqua, et con quel aqua et / con detta masticatura di grano anderai ad una forca o patti/bulo d'un impiccato et da detta forca taglierai delle steche / o schaglie di ligno et ne accenderai un fuoco et in quello con-/cuocerai il pane tondo fatto di detta masticatura et aqua et / quando sarà cotta detta misticatura piglia un carbone di/ quelli rimasti et con esso farai sotto la medesima forca o / patibolo un circolo, come qui sotto si vede.

Pane - pizza $^{68} / /$

Fatto il circulo entravi dentro con la pizza, o pane in mano, / et chiama tre volte Candur, Candur, Candur et vi conpari-/rà avanti un huomo nero con un mantello, et vi diman-/dera il pane et voi chiedetegli il mantello, ne mai / gli darai il pane, se prima non ti da il suo mantello et / questo portato á dosso sarai invisibile. (Cod. Mag. 46, 1r-2v)

[The VeIL OF INVISIBILITY / OR / MARVELOUS SECRET / To go to any place unseen. / 123 // To go unseen. / In that time that the wheat is about to be / harvested, or reaped, or mowed, you will go to nine different / fields and from each of them you will take a little bit of wheat and / you will chew all of them one at [a time] with your [lit. the] teeth, so that it will be possible to fill [lit. to make] a / new earthenware vase, at the water well, and with that water and / the wheat that has been chewed [lit. the mentioned mastication of wheat] you will go to the gallows / of a hanged man and from those gallows you will cut rods / or flakes of wood and from them you will light a fire and on it you will / bake the

66. Note esp. misticatura in 2r, 10, used in Tuscan sources from the fourteenth century to refer to something that was previously chewed and then applied on a wound (e.g., leaves); see the relevant lemma in Tesoro della Lingua Italiana delle Origini (Thesaurus of the Italian Language of Origins), http://tlio.ovi.cnr.it/TLIO/, hereafter TLIO.

67. Here and below, the accent mark for the word invisibilità (invisibility) is omitted. The letter $u$ is added over the line as emendation for the word luogo (place). The number 123 indicates the numeration of the manuscripts in the Leipzig Collection according to Schröer's Catalogus Rariorum Manuscriptorum (Catalog of rare manuscripts).

68. The words Pane - pizza are written in red; above the inscription, an oval bread is drawn, also in red ink. Both the bread and the words are inscribed in a circle drawn in black ink, the same color of the text of the recipe (fig. 3). 
round bread made of that mastication and water. And / when that mastication is baked, take a coal from / those left and with it you will draw [lit. make] under those gallows / a circle, like [the one] you can see below.

Bread - pizza //

Once the circle is drawn [lit. made], enter it with the pizza, or bread in [your] hand, / and call for three times Candur, Candur, Candur, and a black man / will appear to you with a coat, and he will / ask you for the bread and you shall ask him the coat, and you shall never / give him the bread, if he does not give you the coat first. And / by wearing that [coat] [lit. and that worn] you will be invisible.]

Paris, Bibliothèque nationale de France, Grec. 2419 (Codex Parisinus 2419) Another long version of the recipe for invisibility that closely parallels the text in the Vatican manuscript and in the Leipzig fragment is transmitted in BnF 2419 (Ridolfi manuscript), an extensive paper codex of 342 leaves in Byzantine Greek, today preserved at the National Library of France. ${ }^{69}$ Copied in 1462 by Georgios Midiates, the codex transmits much earlier textual material on magic, divination, astrology and occult sciences. Unfortunately, little is known about Midiates. ${ }^{70}$ Judging from the content of his large volume, he was a Christian intellectual interested in Jewish occult lore, among other things. Throughout the codex, Midiates occasionally uses Hebrew characters, often with nikkud (Hebrew point system for vocalization), for rendering specific words in Greek, thus demonstrating that he had enough knowledge of Hebrew to read and copy from Hebrew sources. ${ }^{71}$

The history of the transmission of the Ridolfi manuscript points to an interesting connection of this source with Italy and, therefore, may explain its relationship with the Vatican codex and the Leipzig fragment. Between the years 1517 and 1550 (but likely after 1535), it passed into the hands of the Florentine cardinal Niccolò Ridolfi (1501-50), a grandson of Lorenzo the Magnificent through his mother Contessina de Medici. Introduced by his uncle Pope Leo X to the rich Medicean

69. Franz Boll et al., Catalogus codicum astrologorum graecorum, vol. 8 of 12 (Brussels, 1929), pt. 1:2063, 43; Paul Magdalino and Maria Mavroudi, "Introduction," in The Occult Sciences in Byzantium, ed. Paul Magdalino and Maria Mavroudi (Geneva, 2006), 11-37, 24-25. The codex preserves another recipe for invisibility on 144v, edited in Delatte, Anecdota Atheniensia, 1:457.

70. Herbert Hunger, Repertorium der griechischen Kopisten 800-1600, 3 vols. (Vienna, 1981-89), $2: 53$.

71. On the cypher (Hebrew characters used as allography to write Greek words) used in BnF 2419, see Delatte, Anecdota Atheniensia, 446; for other examples of its use, see Michael Zellmann-Rohrer, "A Syriac-Arabic Dream-Request and Its Jewish Tradition," Journal of Near Eastern Studies 78, no. 1 (2019): 59-74, 71-72. 
collection of manuscripts (kept in Rome before returning to Florence during the papacy of Clement VII, in 1523-34), Ridolfi began to build his own library during the first years of his cardinalate (i.e., after 1517). He purchased many Greek manuscripts from the physician and humanist Niccolò Leoniceno from Vicenza and from the Greek scholar John (Janus) Lascaris. The Ridolfi manuscript was probably acquired only after $1535 .^{72}$ Following Ridolfi's death, the codex was added to the library of Piero Strozzi, marshal at the service of the French monarchy. Upon Strozzi's death at the siege of Thionville (1558), his cousin Queen Catherine de' Medici added to her own collection 800 Greek and Latin manuscripts from his library, apparently without honoring the promise of paying his heirs in exchange. The Ridolfi manuscript was brought to France with the other manuscripts and, along with them, eventually annexed to the royal library of France: ${ }^{73}$

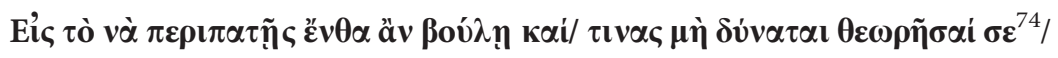

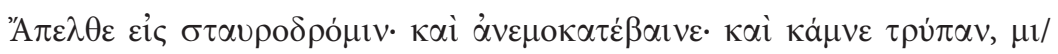

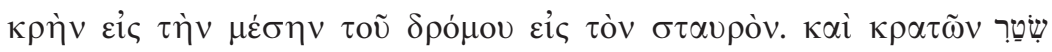

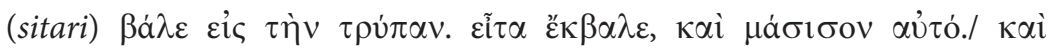

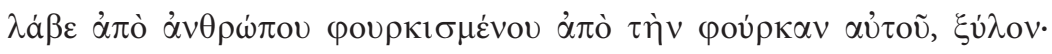

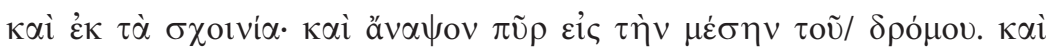

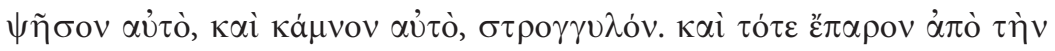

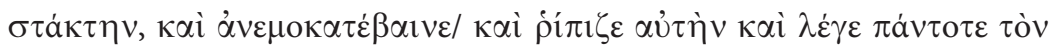

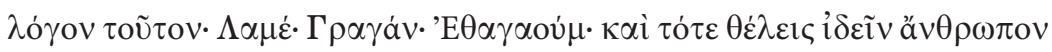

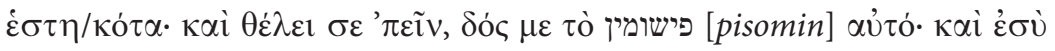

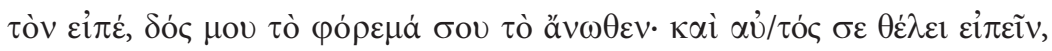

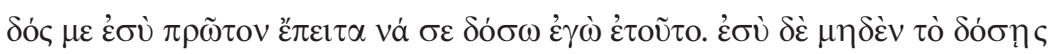

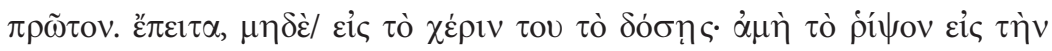

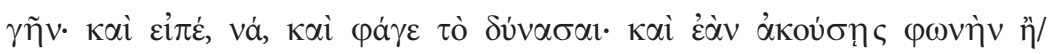

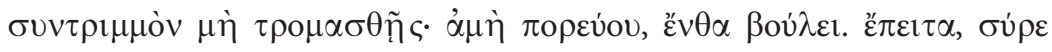

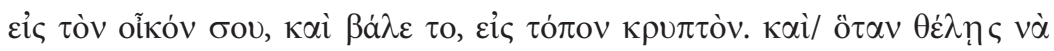

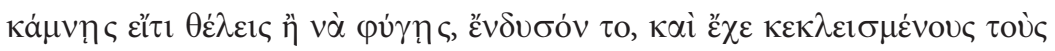

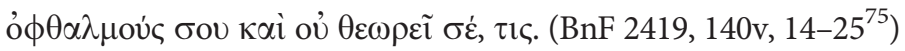

72. Neither the inventory of Ridolfi's library produced around 1525 nor the list of Lascaris's books in the possession of Ridolfi copied in the mid-1530s mention BnF 2419. On Ridolfi's library, see Davide Muratore, La biblioteca del cardinale Niccolò Ridolfi (Alessandria, 2009).

73. Giuseppe Mazzatinti, Inventario dei manoscritti italiani delle biblioteche di Francia, 3 vols. (Rome, 1886-88), 1:115.

74. As with the other recipes in the codex, the title is written in a different ink in the right side of the page, $140 \mathrm{v}, 14-15$.

75. With minor differences, my transcription follows Delatte, Anecdota Atheniensia, 1:448-49, where the Greek words in Hebrew characters are rendered, albeit in Greek letters. 
[To walk around wherever you want and no one will be able to see you. Go to a crossroad and go as fast as the wind [?] ${ }^{76}$ and make a little hole in the middle of the road at the cross point and holding a little corn-dough [שָטֵ), sitari], ${ }^{77}$ put it in the hole. Then, take [it] out and chew $^{78}$ it. And take wood from the gallows of a hanged man and [some] of the ropes and light a fire in the middle of the road and rub it [knead the corn-dough] and make it round. And then, take oil of myrrh and go as fast as the wind and fan it into flame and say each time this formula: "Lamé, Gragàn, Ethagaùm" [ $\Lambda \alpha \mu \varepsilon$,

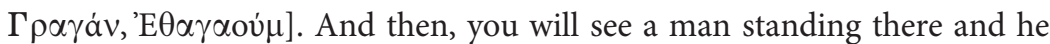
will tell you: "Give me that morsel [פישומין, pisomin] him: "Give me your upper garment"; and he will tell you: "You give [it] first to me, and [then] I will give you this." But you shall not give it first. Thereafter, you shall not place it in his hand, but throw [it] to the ground and say: "Here: eat what you can." And if you hear a sound or a [sound of something] breaking, do not fear, but go on where you wish. Then, take it [the garment] to your house and put [it] in a hidden place, and whenever you wish to do whatever you want or to flee, put it on and keep your eyes closed, and no one will see you.]

\section{New York, Jewish Theological Seminary, 8114}

JTSL 8114 is a Hebrew codex of Italian provenance that features 142 vellum leaves written on both sides and filled with different magical and kabbalistic excerpts, sections on dream interpretation and palmistry, and permutations of divine names, as well as recipes and remedies for various purposes. ${ }^{80}$ The first section of the codex (1-113), which includes several magical diagrams and drawings, is written in a fourteenthcentury Ashkenazi square script fully vocalized, while the second (114-42) is copied in a fifteen-century Italian unvocalized cursive. The section dated to the fourteenth century transmits a recipe for "acquiring the garment of the demons" (27v, 7-11) that shares several features with the instructions for attaining invisibility found in the short and long versions discussed above, thus representing the earliest (or one

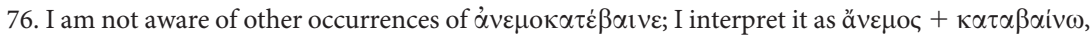
with the meaning of "going as fast as the wind."

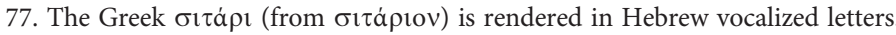

78. Probably a form of the later Greek verb $\mu \alpha \sigma i \zeta \omega$ (chew); see Erich Trapp, ed., Lexikon zur byzantinischen Gräzität besonders des 9.-12. Jahrhunderts, 8 vols. (Vienna, 1994-2017), http:// stephanus.tlg.uci.edu/lbg; hereafter cited as $L B G$.

79. The Greek $\psi \omega \mu$ iv (later syncopated form from $\psi \omega \mu$ iov) is rendered in Hebrew letters.

80. Adolph Lewisohn, Catalogue of the Private Library of Mr. Adolph Lewisohn (New York, 1923), 56. 
of the earliest, together with JTSL ENA 2948.10) source associated with this magical tradition. Like most of the other texts in the codex, the recipe is written in an ungrammatical Hebrew and often exhibits an incorrect use of the nikkud (Hebrew vowel-points):

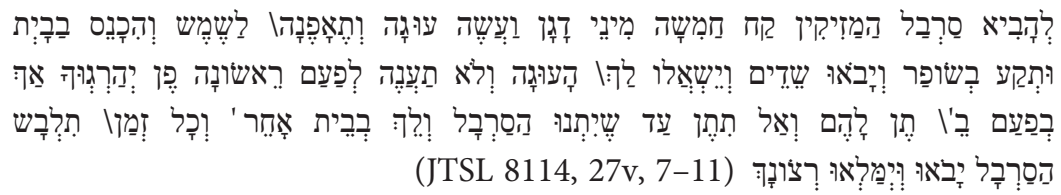

[For bringing the garment of the demons [lit. the harmful ones]. Take five types of cereals and make a round bread and bake it / under the sun, and enter in the house and blow the shofar [animal horn used in Jewish religious practice], and demons will come and ask you for / the round bread and do not answer the first time otherwise they will kill you, but the second time / give [it] to them and do not give [it] until they give [you] the garment and go to another house. And every time / you wear the garment they [the demons] will come and fulfill your wish.]

\section{RITUAL DYNAMICS AND MAGICAL LOGIC}

According to the Jewish and non-Jewish manuscript sources surveyed in the previous section, the recipe for going unseen describes a multistage ritual that involves the manipulation of natural elements, the enactment of magical acts in a specific place, and the inscription of a magical object or the utterance of magical formulae, as well as the encounter with a nonhuman entity. The complex ritual is functional to the attainment of a specific magical object, a garment that makes the individual who wears it invisible to human eyes. The ultimate logic behind the magical technique seems to follow the principle of contagion: by coming into direct contact with-that is, by wearing - a specific object that is believed to possess the property of invisibility, one temporarily obtains that property, as the titles of all the recipes confirm.

While the short version merely expresses the goal of not being seen by anyone, the long version points to the specific context of traveling and to the possibility of using the property of invisibility for escaping. While in other cultural traditions techniques for going unseen were often conceived as illusionistic tricks aimed at amusing the magician's circle ${ }^{81}$ in Jewish magic the pursuit of invisibility was mostly a practical undertaking associated with protection and self-defense-that is, becoming invisible in order to escape from enemies of different sorts. This trend 113-24. 
may well reflect the precarious condition of Jews in medieval and early modern Europe, who-as members of a persecuted minority—might have resorted to magic, among other things, to face the threat of attacks by Christians. In the cognate specimen JTSL 8114, the achievement of invisibility is not explicitly mentioned in the text. Yet, the demons' garment is described as a magical object with the power of enabling those who possessed it to achieve whatever they wished, possibly also becoming invisible.

\section{The Pantry of the Chef}

According to all the manuscripts, the first stage of the magical enterprise consists in procuring a few magical ingredients, all simple culinary elements that would have been easy to locate even within a household. All the sources refer to different types or derivatives of wheat-grano (wheat); חיטין (grains of wheat); חמשה מיני דגן (five

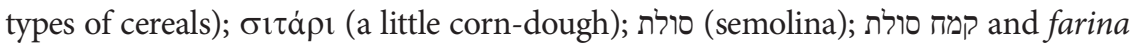
di fiore (fine flour) — which are required in the subsequent magical stages for producing edible food. Most manuscripts transmitting the short version suggest procuring honey as an additional ingredient, while the Leipzig fragment advises the use of well water. According to all the sources, the different elements are mixed together to bake a wheat-based dish. The long version refers, though, to an additional ritual stage before baking the food, during which the corn-dough/wheat is chewed by the user (Ridolfi manuscript and Leipzig fragment) and then left for a certain period in a specific place, either a hole dug in the ground at a crossroad (Vatican manuscript) or a new earthenware vase (Leipzig fragment). In culinary terms, this corresponds to the leavening phase; according to the logic of magic, it represents a transformative stage. The magical transformation of the dough is further emphasized in the Vatican manuscript. The recipe describes, in fact, a procedure that lasts for nine days, during which the user observes specific norms concerning time, space and interaction with other human beings, and utters a magical formula after burying the grains in the hole and when retrieving them.

\section{Crucifixion Sites, Gallows, and Crossroads}

Once the user has obtained or retrieved the wheat/dough, s/he is instructed to reach a site of execution where the most important stage of the magical practice is expected to unfold, namely lighting a fire and conjuring up an otherworldly entity. ${ }^{82}$ According to the short version of the text, the specific nature of the site of execution is left unclear. Both the Hebrew תלוי and the Italian appiccato point to a 
form of capital punishment that could assume several different forms-death by crucifixion, hanging on a noose, or impalement-and emphasize the suspension of the human body, before or after death, rather than the actual lethal method with which the death of the victim is perpetrated. ${ }^{83}$ The reference to a tree is not sufficient to exclude crucifixion, which could be actually implemented on trees. ${ }^{84}$ The long version employs a clearer terminology. Yet, while the Hebrew צליבה in the Vatican manuscript seems consistent with crucifixion, both the Ridolfi codex and the Leipzig fragment point to a specific instrument of death by hanging. The Italian forca (cf. Latin furca 'gibbet') and, especially, pattibulo d'un impiccato clearly refer to the gallows, and so does the Greek substantive фoú $\rho \kappa \alpha$ (gibbet) and the verb

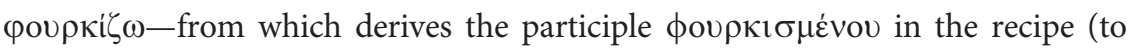
gibblet/to hang by the neck). ${ }^{85}$ In the Ridolfi manuscript, the identification with a site of execution by hanging is reinforced by the mention of ropes ( $\tau$ ò $\sigma \chi o$ ovía) with which the user is instructed to light the fire.

The site of execution and the specific elements retrieved there are pivotal in the unfolding of the magical enterprise. By standing near the place where a man violently died and taking a piece of the tree, cross, or gallows on which he was killed, users believed they could channel the powerful energy related to that specific death and summon the specific deceased. The explicit reference to a site of execution in the recipe, then, may reflect later developments in the practice of invoking the souls of the biaiothánatoi (those who suffered a violent death, such as executed criminals, gladiators, and heroes) ${ }^{86}$ Because their time on earth was not completed and they were unable to find peace in the underworld, the biaiothanatoi represented an attractive resource in Greco-Egyptian and Greco-Roman magic. For their greater proximity to the world of the living and their particular condition, they were, in fact, easier to summon and corrupt than other deceased. ${ }^{87}$

83. For the meaning of the Hebrew תלוי (suspended) in biblical, Second Temple, and rabbinic literature, see David W. Chapman, Ancient Jewish and Christian Perceptions of Crucifixion (Tübingen, 2008), 14. The Italian passive participle appiccato is documented in medieval literature in the sense of both "hung on the cross/crucified" and "hanged" (TLIO, appiccato).

84. Antonello da Messina, Antwerp Crucifixion (1454-55), Royal Museum of Fine Arts of Antwerp. In Hebrew, the term תלוי is often paired with the expression על עץ (on a tree), and in several languages_including Latin (lignum) and Greek ( $\xi \dot{v} \lambda \mathrm{ov}$ ) — tree or wood may refer to the cross.

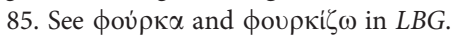

86. Jan Hendrik Waszink, "Biothanati," in Reallexikon für Antike und Christentum, ed. Theodor Klauser (Stuttgart, 1954), pt. 2:391-94; Sarah Iles Johnston, Restless Dead: Encounters between the Living and the Dead in Ancient Greece (Berkeley, 1999), 127-60.

87. Luke A. R. Evans, "Recipes for Love: A Semiotic Analysis of the Tools in the Erotic Magical Papyri” (PhD diss., Durham University, 2016), 113-14. 
Unlike the other sources, the Byzantine manuscript does not refer to the gallows as the place where the magical ritual takes place, but merely as the site where users are required to collect part of the materia magica. According to this source, in fact, the entire magical praxis is enacted at a crossroad (á $\pi \varepsilon \lambda \theta \varepsilon \varepsilon i \varsigma, \sigma \tau \alpha v \rho o \delta \rho o ́ \mu t \nu)$. Due to their intrinsic liminality and the idea of multilocation they evoke, crossroads have been chosen as the preferential setting for magical ritual practice in many different cultures since antiquity. ${ }^{88}$ The reference to a crossroad is also found in the Vatican manuscript, where the crossroad (פרשת זרכים) represents the ritual setting of only the first stage of the magical enterprise. Although the Leipzig fragment does not refer to a crossroad, it preserves the distinction between the two different ritual settings for the first and last sessions of the magical operation. The discrepancies in the nature of the ritual setting(s) of the magical enterprise may derive from either a mistaken or explanatory reading of a version of the recipe similar to the one preserved in the Ridolfi codex. Specifically, the variant צליבה in the Vatican manuscript - the only one that explicitly points to crucifixion-may have originated from a misinterpretation of the Greek word $\sigma \tau \alpha$ póc. While it can refer to an instrument of suspension punishment and usually to a cross (cf. Hebrew, צלוב/צלב

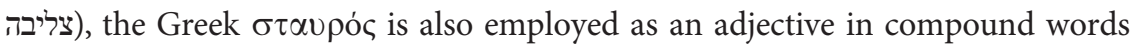
to indicate an item that is cross-shaped, such as the meeting point of two roads

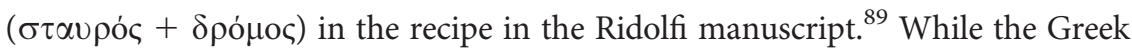
source leaves unsaid how and at which point of the magical operation users are supposed to retrieve wood and ropes from the gallows, the Hebrew and Italian versions of the recipe resolve the conundrum by simply shifting the ritual setting to the site of execution exactly when users are instructed to procure wood and light a fire.

\section{Baking a Pizza ...}

Wood and ropes are used to light a fire that becomes itself a forceful magical device on which the user is required to bake a wheat-based dish, after kneading together the magical ingredients. In the manuscripts preserving the short version, the instruction to be careful not to burn the dish-which sounds more like the recommendation of a pastry chef rather than a magical imperative-confirms that the magical object created during the ritual needed to be edible, thus hinting at its ultimate function, that

88. In ancient magic and, specifically, within the corpus of the Greek Magical Papyri, crossroads were regarded as liminal places, where the encounter between the living and the dead was deemed possible; Sarah I. Johnston, "Crossroads," Zeitschrift für Papyrologie und Epigraphik 88 (1991): 217-24.

89. Although the verb $\sigma \tau \alpha$ opó $\omega$ is the most used in the New Testament in relation to the cruci-

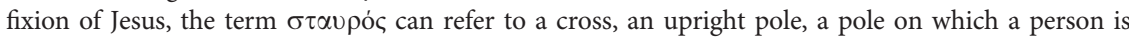
impaled, or a stake; Chapman, Ancient Jewish and Christian Perceptions, 9-10. 
of being offered and eventually eaten by the otherworldly entity summoned by the user. $^{90}$ To refer to the dish prepared and baked during the magical ritual, all the Hebrew sources employ the Hebrew term עוגה, which in biblical and rabbinic Hebrew translates "round bread." This interpretation is reinforced by the variants in the Italian and Greek sources. The former adopt the term pizza, which in the Leipzig fragment is used together with the expression pane tondo (round bread) and rendered visually with a drawing of the dish (fig. 3). In medieval Italian vernaculars, pizza did not refer to the famous Neapolitan pizza, but indicated bread in general and, specifically, a sort of focaccia. ${ }^{92}$ Pizzas could also represent sweet dishes and sweet pizza cakes were common in Italian-Jewish cooking. ${ }^{93}$ The reference to honey in the short version may point to a sweet bread of this type, something like the pizza ebraica or pizza di Beridde-still baked today in the old bakery of the ghetto of Rome-a delicious rhombus-shaped/rectangular (not round as the drawing in the Leipzig fragment!) cake made of sugar, oil, red wine, almonds, raisins, pine nuts, and candied fruit. The Greek version in the Ridolfi manuscript also refers to a round corn bread ( $\sigma \iota \tau \dot{\alpha} \rho ı v v \sigma \tau \rho o \gamma \gamma \nu \lambda o ́ v)$. Significantly, in the Greek version, the expres-

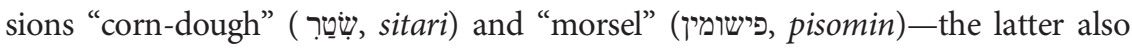
employed to refer to the bread as the offering-token-are written in cryptographic script in Hebrew characters. The use of the cypher for both the ingredient necessary to produce the bread and the bread itself at the moment of the offering may be explained as an attempt to limit access to these important stages of the ritual praxis and, therefore, to protect the business of the magician.

90. On the offering of food in Greco-Egyptian magic, see Joachim F. Quack, "Postulated and Real Efficacy in Late Antique Divination Rituals," Journal of Ritual Studies 24 (2010): 45-60, esp. 47 and 54; Johnston, Restless Dead, 38-46. For similar traditions in Jewish magic, see the famous pre-Islamic Jewish grimoire Sefer ha-Razim, edited in Mordechai Margalioth, Sepher Ha-Razim: A Newly Recovered Book of Magic from the Talmudic Period [in Hebrew] (Tel Aviv, 1966), esp. 76-77; and in Bill Rebiger and Peter Schäfer, eds., Sefer ha-Razim I und II: Das Buch der Geheimnisse I und II, 2 vols (Tübingen, 2009), esp. 1:*30-31.

91. James Hastings, ed., Dictionary of the Bible: Including the Biblical Theology, 4 vols. (New York, 1909), 1:315-18; Marcus Jastrow, A Dictionary of the Targumim, the Talmud Babli and Yerushalmi, and the Midrashic Literature, 2 vols. (New York, 1903), 2:1047; see also two magical recipes that involve the preparation and ingestion of cakes/breads in Margalioth, Sepher Ha-Razim, 75-76, 90; and in Rebiger and Schäfer, Sefer ha-Razim I und II, $1:{ }^{\star} 29-31 ;{ }^{\star} 58-59$.

92. Mario Alinei and Ephraim Nissan, "L'etimologia semitica dell'it. pizza e dei suoi corradicali esteuropei, turchi, e dell'area semitica levantina," in Quaderni di Semantica: An International Journal of Semantics and Iconomastics 28, no. 1 (2007): 117-35.

93. Ephraim Nissan and Mario Alinei, "The Pizza and the Pitta: The Thing and Its Names, Antecedents, and Relatives, Ushering into Globalisation," in Onomastics in the Contemporary Public Space, ed. Oliviu Felecan and Alina Bugheşiu (Newcastle, 2013), 328-39, 123-24. For Italian-Jewish sweet pizzas, see Ariel Toaff, Mangiare alla giudia: La cucina ebraica in Italia dal Rinascimento all'età moderna (Bologna, 2000), 75-76, 152. 


\section{... for the "Uomo Nero"}

After discussing the production of the bread, the recipe shifts to the apparition of an otherworldly creature with whom the user is instructed to communicate according to certain rules in order to obtain the desired magical object. The sudden appearance of this character in the magical setting does not seem directly related to the preparation of the bread. Rather, his arrival is linked to the lighting of the fire made with the logs and ropes taken from the site of execution, a magical act that turns out to have, then, a double function, that is, ensuring the production of the magical object as well as the conjuration of a spirit. In the Leipzig manuscript, the instruction of drawing a (black) circle on the ground with coal from the fireand the visual representation of the circle given in the manuscript (fig. 3)-clearly points to traditions of demonic magic and to conjuring demons. ${ }^{94}$ The circle defines a new, more circumscribed, magical area into which the user is required to enter with the bread in order to summon the demonic creature, and within which the summoned entity is believed to be contained.

The identity of the apparition is unclear. While the versions of the recipe in JTSL ENA 2948.10 and in the cognate specimen JTSL 8114 refer generically to demons (respectively, שדים and בהמון גוים), the other sources seem to point specifכדמות כeally to a human-like apparition, demonic or not. The Hebrew expression אדם (an apparition in the image of a man) in GFC 325 and JTSL 1729 is commonly attested to in Jewish magical-divinatory literature, where-often juxtaposed with expressions mentioning "fire," as in the recipe under discussion-is employed to describe revelatory experiences aimed at gaining hidden knowledge or to portray the summoning of otherworldly entities. ${ }^{95}$ According to the Greek and Italian versions of the recipe (BnF 2419, GFC 325 and JTSL 1729) the figure is simply a man (respectively, å $v \theta \rho \omega \pi \mathrm{o}$, and un uomo). The description of the apparition of a black man (with a coat) in the Vatican manuscript and the Leipzig fragment (respectively, אדם שחור, האיש השחור and un huomo nero con un mantello), is more

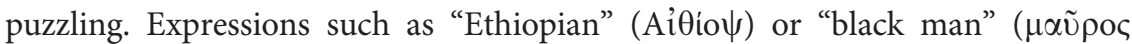
ăv $\theta \rho \omega \pi \mathrm{)})$ were commonly used in Greek magical lore to refer to demons and were appropriated in later magical traditions. ${ }^{96}$ Analogous expressions resurface also in Renaissance hagiographic accounts of the spiritual (and physical) battle

94. Kieckhefer, Forbidden Rites, 170-80.

95. See the excerpt edited in Margalioth, Sepher Ha-Razim, 79; and in Rebiger and Schäfer, Sefer ha-Razim I und II, 1:*34-37; discussed in Bellusci, Dream Requests.

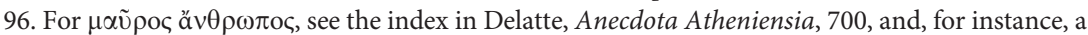
recipe for casting out a demon that is haunting a buried treasure by first making it appear to a boy in the form of a "black man" (äv $\theta \rho \omega \pi$ ov $\mu \alpha \tilde{v} \rho o v), 64$. 
of the sante vive against the devil, who is described as a "Moor" or "Ethiopian." It is possible that Italian folkloristic traditions of the uomo nero-an entity analogous to the bogeyman-also derived from demons anthropomorphized as men of color. The (black) human apparition mentioned in most of the sources may also be interpreted as a reference to the executed man. In this perspective, the detail regarding the color of the human apparition reflects a widespread prejudice toward foreigners, "exotic" people, and men of color. ${ }^{98}$

In all the sources and, especially, in the Ridolfi manuscript-which preserves an extended dialogical exchange-the interaction between the user and the summoned apparition is described as a game of power regulated by specific rules. According to both the Hebrew and Italian versions in GFC 325 and JTSL 1729, the user is admonished to remain silent and do nothing but hand over the bread, on which a specific question has been inscribed. The sources transmitting the long version and the cognate specimen in JTSL 8114 specify that users can fulfill their will only if they deliver the offering token after having first received the magical garment by the otherworldly entity, an instruction that points to a certain mistrust regarding the apparition. While most of the sources merely reassure the user not to fear the summoned entity, in JTSL 8114 the apparition is clearly perceived as very dangerous (פן יהרגוך, “otherwise they will kill you”).

\section{The Coat of Invisibility}

All the sources explicitly refer to a magical garment that confers invisibility, yet they do not specify its nature. The short version refers to a generic piece of clothing, given the neutral Hebrew and Italian terms מלבוש and vestito. ${ }^{99}$ The long version and the cognate specimen in JTSL 8114 seem to point instead to a wrap

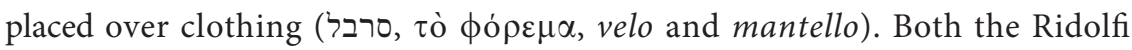
manuscript and Leipzig fragment imply that the garment belonged to the executed man who appeared to the user, presumably the very cloths from which he was

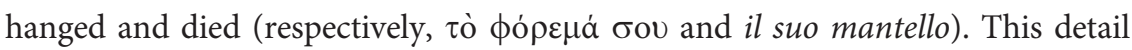

97. Gabriella Zarri, Le sante vive: Profezie di corte e devozione femminile tra '400 e '500 (Turin, 1990), 117 and 157 n. 243, with reference to the vision of Osanna Andreasi (1449-1505).

98. Debra Higgs Strickland, Saracens, Demons, and Jews: Making Monsters in Medieval Art (Princeton, NJ, 2003); Geraldine Heng, The Invention of Race in the European Middle Ages (Cambridge, 2018).

99. In late Jewish magical texts and especially in those associated with kabbalistic circles, the expression מלבוש refers to the doctrine of wearing the divine Name proper to the tradition of Sefer ha-Malbush (The book of the garment); see Irina Wandrey, "Das Buch des Gewandes" und "Das Buch des Aufrechten": Dokumente eines magischen spätantiken Rituals, ediert, kommentiert und übersetzt (Tübingen, 2004). In this specific context, though, it simply means "garment." 
reinforces the hypothesis that the conjured entity was the spirit of the executed man from whose stake users were instructed to take wood or ropes. It also connects to earlier magical traditions involving the spirit, corpse or organic remains of those who died a sudden or violent death.

\section{Magical Formulae}

With the exception of the cognate specimen in JTSL 8114, all the identified sources involve the use of linguistic magic, either written or uttered. ${ }^{100}$ Most of the manuscripts transmitting the short version refer to a form of magical writing, by instructing the user to inscribe the round bread with a specific question-presumably, their request for a coat of invisibility. ${ }^{101}$ The bread, then, not only represented a token of exchange, but also a concrete means for delivering the user's message to the summoned entity.

In the long version, magical words and formulae need to be uttered instead. In the Leipzig fragment, Candur is the magical name that users are instructed to call three times while holding the bread inside a magical circle on the ground. Since the utterance of this magical name seems fundamental for ensuring the appearance of the conjured entity, Candur may refer to the personal name of the apparition itself. Alternatively, Candur may be derived from the Latin substantive candor-candōris (from the verb candeō, "I shine") and the corresponding Italian candor(e), which means "brightness/whiteness," both in a concrete and abstract sense (purity of heart/innocence). If this is the case, then Candur is hardly the name of the apparition-who is described in the fragment as a black manand indicates instead a magical word used to evoke brightness, conceived either as the condition for the appearance of the entity from thin air or as the quality of invisibility itself.

In the Greek recipe preserved in the Ridolfi manuscript, the magical formula recited upon the conjuration of the summoned entity includes the three words $\Lambda \alpha \mu \dot{\varepsilon}$, $\Gamma \rho \alpha \gamma \alpha \dot{v}$, 'E $\theta \alpha \gamma \alpha o u$, the meaning of which eludes us. The Hebrew recipe in the Vatican manuscript registers a similar formula, GWRGWN LNYṬYGRṬWN TYṬGRMṬWN, which also consists of three distinct (magical) names and is given twice fully vocalized. ${ }^{102}$ The third name (TYTTGRMṬWN) in the magical sequence may represent a corrupted form of the name Tetragrammaton, which refers to the four-letter Hebrew name of God (YHWH) and which is often mentioned in Jewish

100. In the recipe in JTSL 8114, a musical instrument-the shofar-is used to summon the demons.

101. On the Jewish use of writing magical words and formulae on cakes, see Ivan G. Marcus, Rituals of Childhood: Jewish Acculturation in Medieval Europe (New Haven, CT, 1996).

102. השמות הכתובים למעלה (the names written above), Vat. Ebr. 243, 16r, 7. 
and Christian magical and kabalistic texts. The first name (GWRGWN) may be interpreted as a reference to the Greek myth of Perseus and the Gorgon and may correspond to the second component in the Greek formula ( $\Gamma \rho \alpha \gamma \alpha \dot{v})$. If this is the case, then the second name (LNYTYGRTWN) may be the corrupted form of an epithet or bound adjective in Greek related to the word Gorgon. A reference to the Gorgon in a recipe for invisibility would be quite logical, as it evokes the story of Perseus, who wore the cap of invisibility to escape from Stheno and Euryale after killing their sister Gorgon. ${ }^{103}$ We cannot establish whether the Greek or Hebrew version of the magical formula is the more authoritative. The one in Hebrew — which reads Gorgon - might be based on a better manuscript tradition. Yet, the Hebrew transliteration of the presumably original Greek words might have been corrected at a certain point of the transmission by a well-educated copyist who knew the story of the Gorgon and considered appropriate a reference to the Tetragrammaton.

The Vatican manuscript preserves an additional magical formula that is uttered under the crucifix before lighting the fire: 'WSPYQWL' 'LY 'WSWPY'. The magical sequence is the corrupted-and now mostly unintelligible - version of a magical formula in Italian referring to bones (Italian ossa), perhaps those of the person executed. According to the transliteration in Hebrew characters, the formula consists of three components, which correspond to approximately six words in Italian: os piccola e le os sepia (little bones and cuttlebones). The interpretation of the third component of the formula is tentative: it was likely an adjective or word related to bones, paralleling the first part of the magical spell (os piccola). My interpretation of 'WSWPY' as cuttlebone takes into account that in Italian this internal shell is indicated by an expression that explicitly refers to bones, namely, osso di seppia (lit. bone of cuttlefish) and that organic elements from cuttlefish are often listed among medico-magical ingredients. ${ }^{104}$

\section{ARCHAEOLOGY OF THE TEXT: THE RESHAPING OF AN ARCHAIC}

\section{TRADITION IN RENAISSANCE ITALY}

The seven manuscript sources examined above are presumably representative of only a part of the history of textual transmission and practice of the magical technique for attaining invisibility. Yet, spanning approximately three centuries - with the earliest source dated to the fourteenth century and the latest to the seventeenth century - and pointing to different geographical and religio-cultural settings, these 
manuscripts attest to a relatively wide dissemination of this specific magical technique. With only a few discrepancies, the same recipe for invisibility circulated and was probably enacted in the Byzantine Empire, Italy, Spain, Egypt, and Germany between the fourteenth and eighteenth centuries. ${ }^{105}$ The sources, the majority of which are in Hebrew or preserved in Jewish codices, clearly point to a Jewish transmission of the recipe and, presumably, to an enactment of the parallel ritual practice among Jews. Significantly, though, all the identified sources are connected to Italy and, specifically, to Central-Northern Italy, thus indicating that the magical technique was transmitted and used by Italian Jews and, possibly, by their Christian neighbors. Although written by Christians, the recipe in the Ridolfi manuscript and in the Leipzig fragment may have been copied or reworked from a Jewish source or from a source derived from Jewish magic. Yet the striking analogies between the Hebrew versions of the recipe and its parallels in Italian and Byzantine Greek may be also interpreted as different developments of an earlier-probably non-Jewish-magical tradition.

Several elements in the recipe point, in fact, to an earlier historical context and, specifically, to a late antique Greco-Egyptian magical milieu. If the magical name GWRGWN in the version transmitted in the Vatican manuscript actually leads back to the Gorgon, then this foreign (with respect to Jewish culture) erudite mythological reference may indicate that the magical formula and, possibly, the magical practice associated with it had a non-Jewish origin and were appropriated in Jewish magic at a later time. Similarly, the reference to a place of execution-and, specifically, to a place of crucifixion according to the early sixteenth-century Vatican manuscript-is anachronistic, because crucifixion was no longer practiced in Europe at the time. ${ }^{106}$ Its memory was kept alive by the beautiful paintings of Christ's crucifixion produced in the Middle Ages and in the Renaissance, as well as by wooden statues of the crucified Christ in churches and in votive niches. Yet, by mentioning the wood of a cross or from the tree on which a man is hanged, I do not think that the recipe for invisibility alluded to the use of wood from a crucified Christ or even less likely to a magical use of relics of the holy cross. Similarly, although Jesus was often referred to in rabbinic sources with the pejorative expression

105. The Genizah fragment JTSL ENA 2948.10, which is part of a larger manuscript in Ladino, was probably copied in a Sephardic milieu, but eventually reached Cairo. The Italian fragment Cod. Mag 46 was eventually sold in Leipzig in 1710.

106. For capital execution - and related practices - in late medieval and early modern Italy and Europe, see Nicholas Terpstra, ed., The Art of Executing Well: Rituals of Execution in Renaissance Italy (Kirksville, MI, 2008); Adriano Prosperi, Delitto e perdono: La pena di morte nell'orizzonte mentale dell'Europa cristiana, XIV-XVIII secolo (Turin, 2016). 
"hanged one" (talui, תלוי) ${ }^{107}$ and early modern Jews had access to sacred objects and relicts, the recipe does not refer to Christ or reflect an anti-Christian polemic; nor does it subvert reliquary practices centered on the holy cross. ${ }^{108}$ The צליבה (crucifixion), which reflects a cultural context in which places of crucifixion outside the city walls were still a tangible reality, and certain magical techniques did use material from crucifixion sites. An example of this late antique practice is "the nail of the cross [or, of the crucified]" (מסמר הצלוב) used as an apotropaic devise and regarded as markedly illicit in second-century rabbinic sources. ${ }^{109}$ When copying, reading, transmitting, and using in practice the recipe for invisibility, the place of execution was clearly the public gallows. In this respect, the instructions preserved in the Greek recipe in the Ridolfi manuscript for retrieving wood and ropes at the gallows and then reaching a crossroad make more sense and may indicate a later development in the textual transmission and magical practice of the technique for invisibility. Lighting a fire and conjuring up a spirit at the public gallows would have been quite problematic in early modern Europe, as executions were conducted under the public eye in squares and public spaces. Stealing some ropes-especially if during the night-would have been more manageable.

If my interpretation is correct, then the magical technique for becoming invisible is much earlier that the late medieval and early modern sources documenting it. Although the specific cultural milieu in which the magical practice was first developed and the language in which the related instructions were first written down are probably bound to remain unknown to us, a Greco-Egyptian origin seems plausible. As mentioned, the specific reference to a place of execution and objects that had been touched by the executed man leads back to the belief in the biaiothánatoi. The late antique corpus of the Greek magical papyri includes recipes for erotic and divinatory purposes and for invisibility that advise using the physical remains-for example, blood, bones, an eye, a piece of clothing-of someone who died violently or prematurely; they also refer to performances of the ritual

107. Peter Schäfer, Jesus in the Talmud (Princeton, NJ, 2007), 63-74. Inquisitorial records show that even in early modern Italy Jews continued to argue that Jesus hanged himself; see Caffiero, Legami pericolosi, 200.

108. On the devotion of relics in the medieval period, see Martina Bagnoli, ed., Treasures of Heaven: Saints, Relics, and Devotion in Medieval Europe (New Haven, CT, 2010). On Christian accusations of the desecration of the crucifix by Jews in the Middle Ages, see Kati Ihnat and Katelyn Mesler, "From Christian Devotion to Jewish Sorcery: The Curious History of Wax Figurines in Medieval Europe," in Entangled Histories: Knowledge, Authority, and Jewish Culture in the Thirteenth Century, ed. Elisheva Baumgarten, Ruth Mazo Karras, and Katelyn Mesler (Philadelphia, 2017), 134-58. On the trade of sacred objects and relics by Jews in early modern Italy, see Caffiero, Legami pericolosi, 200-201.

109. Mishnah, tractate Shabbat, 6:10. 
at the tomb of a biaiothánatos. ${ }^{110}$ A particularly relevant example is documented in the papyrus magique de Paris, which transmits an erotic spell aimed at attracting

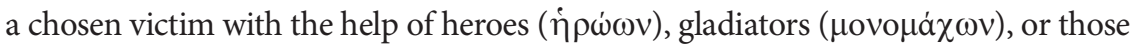
who have died a violent death ( $\beta 1 \alpha i \omega v) .{ }^{111}$ Although the spell does not result in the attainment of invisibility, it exhibits a few analogies with the recipe for going unseen. Users are required to go where the biaiothánatoi died and handle a morsel of bread

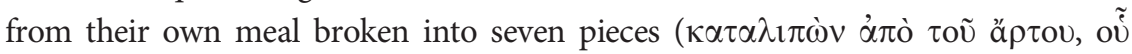

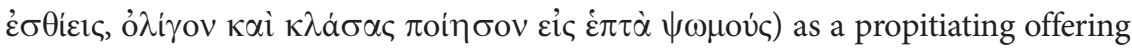
to the invoked spirits. The specification that the bread is a morsel previously chewed by the user-a detail that emphasizes the lowly status of the offering by pointing to the pitiful condition of the summoned entities-connects the late antique spell to the Byzantine magical text in the Ridolfi manuscript in particular. The erotic spell includes two long incantations, one of which is uttered over the bread before it is thrown to the apparition. The incantation is a hymn addressed to the goddess Hecate and a plethora of evil entities - among which are the spirts of the heroes, gladiators, and other dead-who are persuaded to torment the victim until she surrenders to the user's willpower. Significantly, as in the Vatican and Ridolfi manuscripts, the late antique hymn seems to refer to the Gorgon, with Hecate's epithets

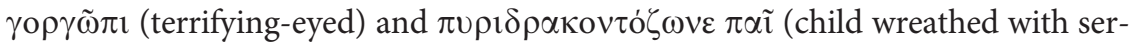

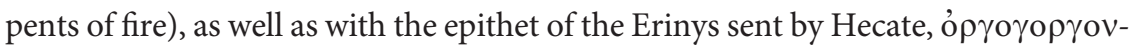
lo $\operatorname{corav}$ (ORGOGORGONIOTRIAN). ${ }^{112}$

The recipe for invisibility preserved in the medieval and early modern manuscripts does not directly stem from the erotic spell in the papyrus magique de Paris. This late antique text documents in great detail, however, the magical practice of conjuring and coercing the spirit of a biaiothánatos by means of a wheat-based dish. It is possible that either at the time the papyrus was copied in the early fourth century or later, this specific technique of conjuration was also used for attaining invisibility, ultimately leading to the development of a magical recipe that may have served as the basis of the variants documented in the later sources studied in this essay.

110. See, for instance, P(apyri)G(raecae)M(agicae) I 247-62, PGM II 1-64, PGM II 64-183, PGM IV 296-466, PGM IV 1872-1927, PGM IV 2785-2890; Karl Preisendanz, Papyri Graecae Magicae, 2 vols., rev. ed. (1928-31; Leipzig, 1973), 1:14, 20-30, 82-88, 130, 160.

111. Paris, Bibliothèque nationale de France, Suppl. gr. inv. 574 (Papyrus Anastasi 1073; PGM IV, papyrus magique de Paris), published in Preisendanz, Papyri Graecae Magicae, 1:64-180. For the erotic spell, see PGM IV 1390-1495; Preisendanz, Papyri Graecae Magicae, 1:118-20; for the translation, Ljuba Merlina Bortolani, Magical Hymns from Roman Egypt: A Study of Greek and Egyptian Traditions of Divinity (Cambridge, 2016), 221.

112. Bortolani, Magical Hymns, 232, 237-38. Hecate's epithets sivo $\delta$ i $\alpha$ (guardian of the roads) and $\kappa u ́ \omega \nu \mu \varepsilon \dot{\lambda} \alpha \iota v \alpha$ (black she-dog) are interesting in light of the references to a crossroad and to the black man in some of the early modern manuscripts transmitting the recipe for invisibility. 
This foreign tradition for becoming invisible may have already entered Jewish magic in the pre-Islamic period, when many magical techniques for different purposes were appropriated and reworked from Greco-Egyptian magical lore. For instance, the pre-Islamic Jewish magical book Sefer ha-Razim (The book of mysteries), which was deeply influenced by Greco-Egyptian magic, includes a recipe that shares many qualities with the recipe for invisibility, such as the need to perform the ritual at the "place of the executed" (מקום ההרוגים). ${ }^{113}$ Yet the lack of attestations of a specific recipe for invisibility based on the belief in the biaiothánatoi in both late antique Jewish sources and among the fragments of the Cairo Genizah suggests that the technique developed in the form known to us only later. ${ }^{114}$ The specific link of all the manuscript sources with Italy, the marked influence of medieval Italian vernacular on the Hebrew texts, and the presence of a magical formula in Italian in the Vatican manuscript (os piccola e le os sepia) and of a Latin one in the Leipzig fragment (Candur, Candur, Candur) indicate that the recipe for invisibility was eventually reshaped in medieval and Renaissance Italy.

We thus have additional proof of the remarkable fluidity and intercultural porousness of magic, and of Jewish magic in particular as it facilitated the circulation of magical lore from the Near-East and Mediterranean throughout Italy. At the same time, it demonstrates that Italian Jews did not refrain from appropriating and reworking foreign magical traditions learned from their Christian neighbors or based on magical books in Latin and Italian. Rather, they actively contributed to the diffusion of a shared magical culture in early modern Italy.

113. Margalioth, Sepher Ha-Razim, 77; Rebiger and Schäfer, Sefer ha-Razim I und II, 1:*30.

114. The fragments uncovered in the Cairo Genizah often are copies of copies of recipes of this genre. To my knowledge, though, there are no pre-Islamic Jewish recipes for becoming invisible that can be related to the specific tradition studied in this article. The version in JTSL ENA 2948.10 is later and was part of a medico-magical notebook in Ladino that probably reached Old Cairo from Europe. 